\title{
九州齒科學會雜誌 第五突
}

昭和十五年十月二十五日發行

\section{原著}

\section{人體健態永久齒牙脂肪, 形態學的 研究補遺}

\author{
東京高等肉科醫學校外科學㸚窒 (主任 中村敎授) \\ 大 橋 三 郎
}

㐫 容 抄 銶

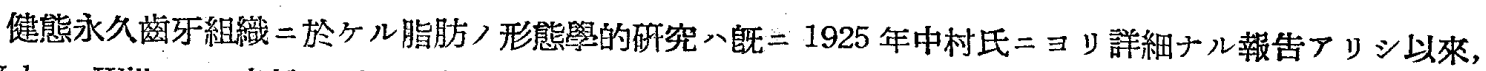
Weber, Willner, 赤松, 國分, 角田, 山田, 伊藤等/諸氏 $=\Xi ル$ 業績

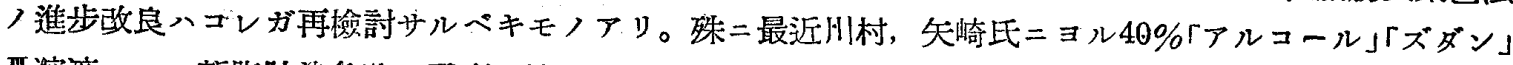

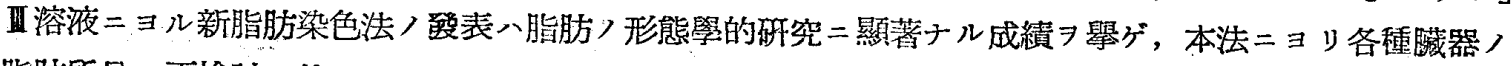

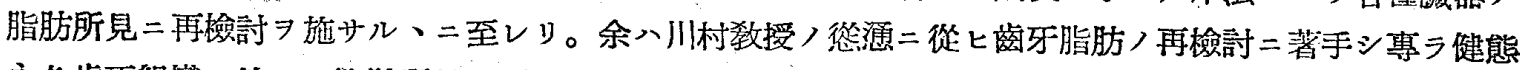

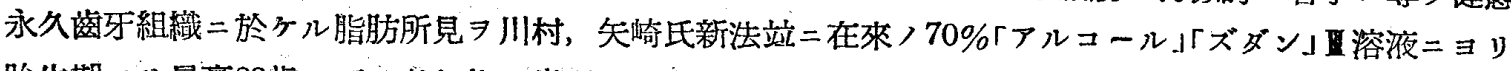

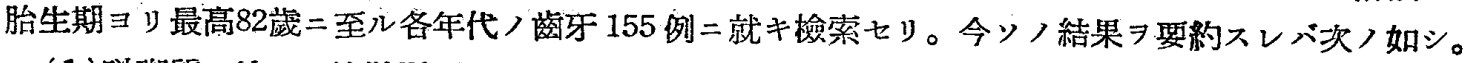

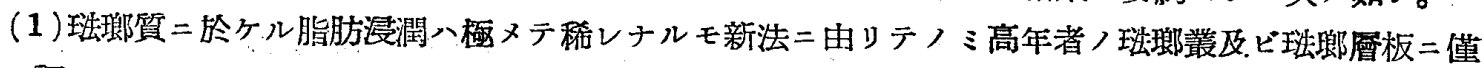
カニ認メラル。

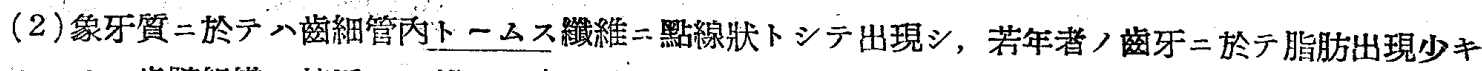

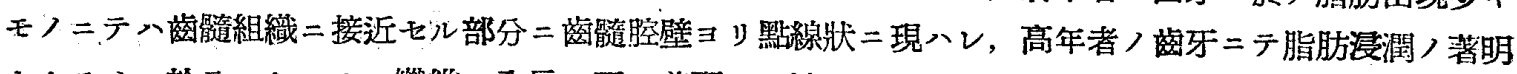
ナルモノニ於ティトームス纖維ノ全長二互り美麗ナル線狀ヨナシ出現ス。而シテ新洗ニテ12歳, 舊法二 テ27歲以上ノ苳牙 $=$ 出現シ，年齡ノ增加ト共ニッノ出現頻度ノ上昇 7 認ム。

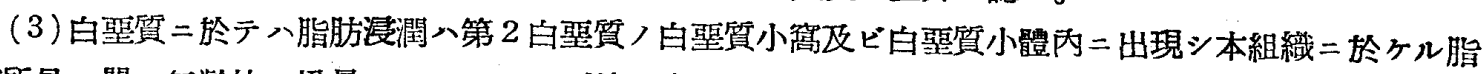

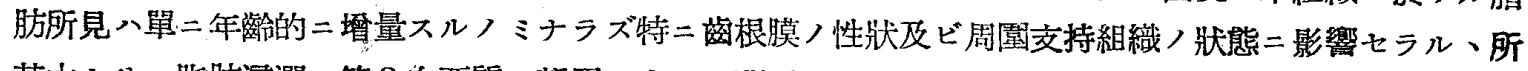

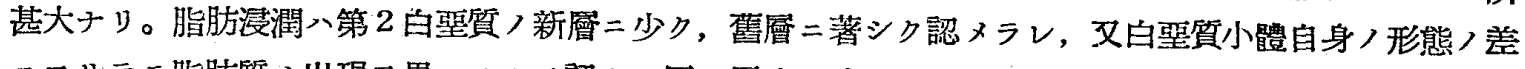
ニョリテモ脂肪質ノ出現 $ᄏ$ 異ニスル

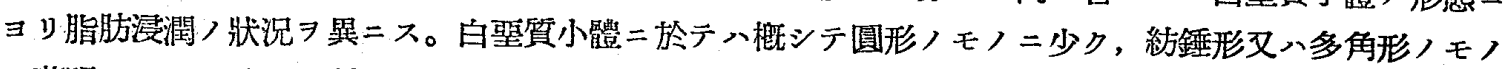

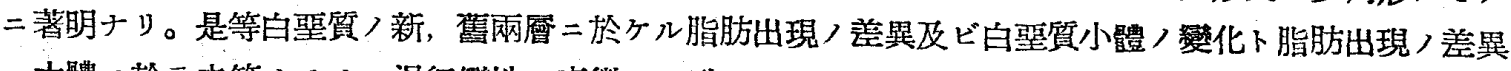
八大體ニ於テ夫等ノモノ、退行變性ノ表徵ト一致スルモノニシテ從ッテ是等ノ脂肪所見

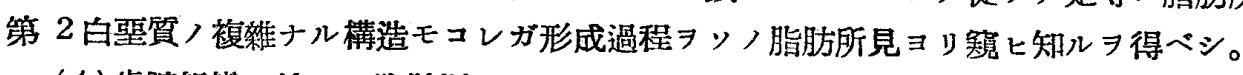

(4)齒膸組織二於ヶル脂肪浸潤八最モ早ク造萄細胞原形質內ノ細胞核外侧二現ハレ, 量ノ增加ト共二

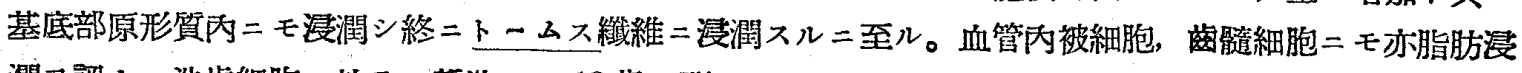

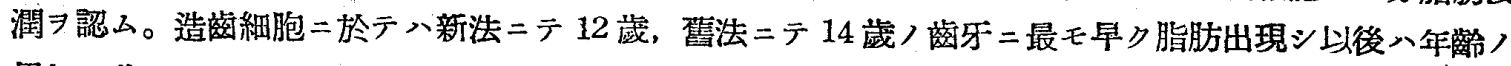
累加ト共ニソノ出現頻度 


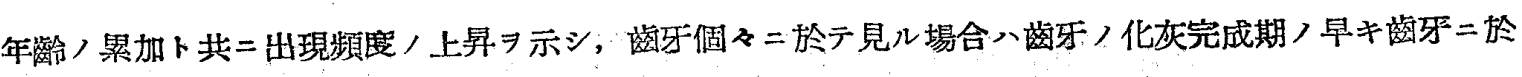
テ最モ早期二脂肪漫潤，生ズル揧實

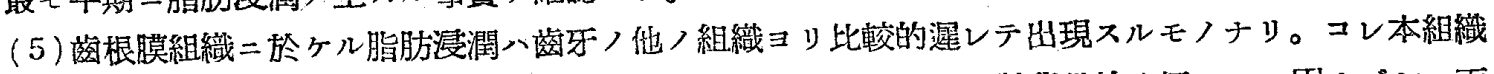

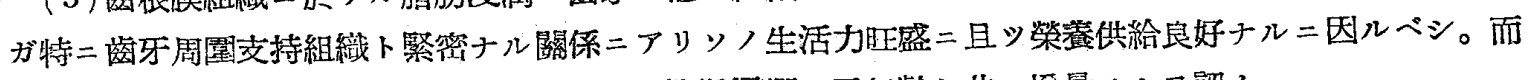
レドモ造白惡細胞，血管內被細胞等二於ヶル脂肪浸潤八又年齡ト共二堙量スルヨ認ム。

(6) 各組織二浸潤スル脂肪ノ形態八新法, 䳡法共二滴狀ヨ呈スルモ新法ニテハ美麗ナル圓形ヨ是スル コト多ク，舊法ニテハ概シテ微細ナリ。色調ハ澵法ニテハ總テ美麗ナル橙赤色ヨ是シ，舊法ニテハ赤褐 色又八黄赤褐色

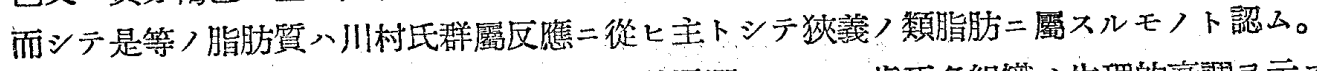

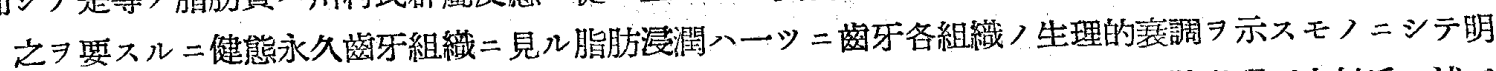
カニ一種ノ老性變化下認メ得ベシ。绱木余ノ研究成績コ於テハ各組織ニ於ケル脂肪出現ガ中村氏ノ述へ

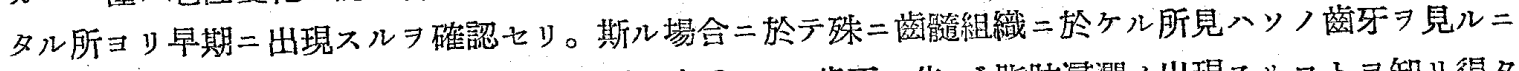

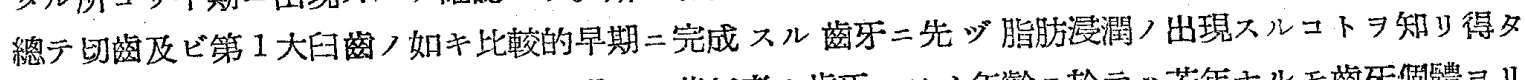

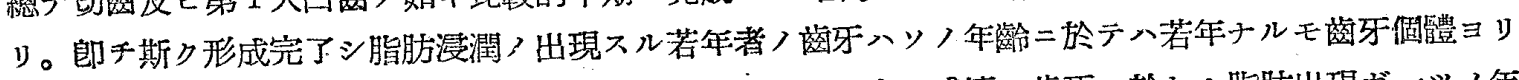

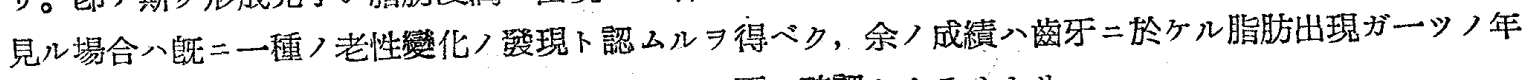
路的變化郎于老性變化ノ結果來ルモノナルコトラ更二確認セルモノナリ。

\section{第 1 音 縉事}

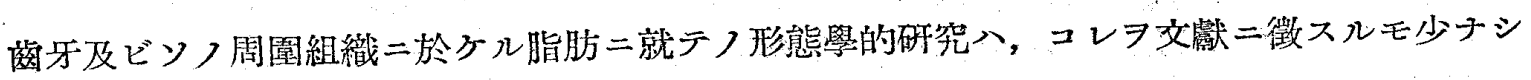

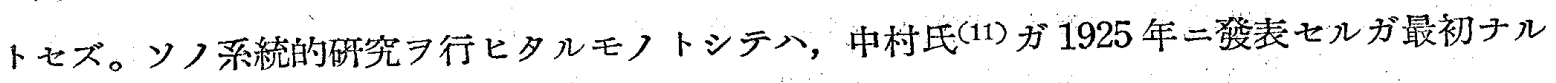

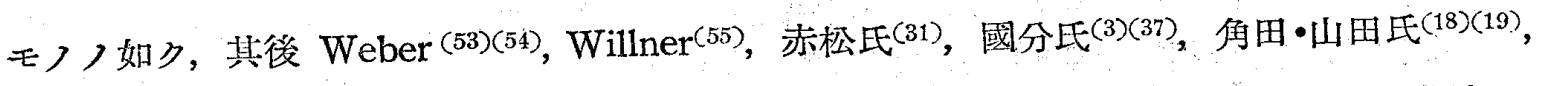

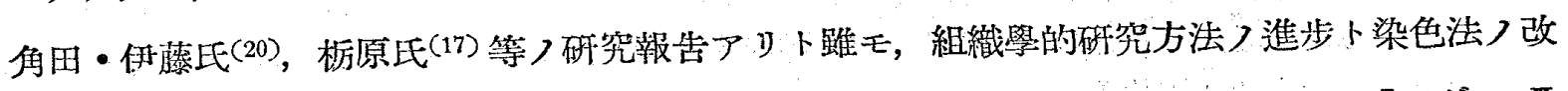
良ニヨリ再檢討サルベキモノアリ。殊二川村・矢崎氏(4)(5)=ヨル40\%「アルコール」「スダン」且 溶液ヨ以テスル一新脂肪染色法ノ發表二ヨy脂肪つ形態學的研究二顯著ナル成績

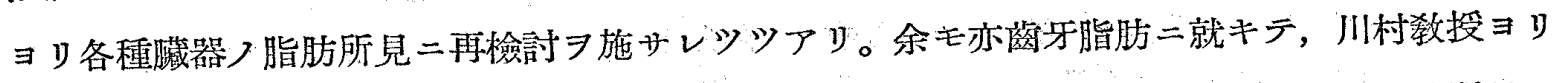

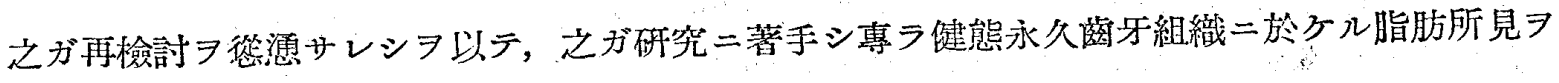
檢索シタルラ以テ茲ニ報告セントス。

\section{第 2 章 研究材料及ビ研笲方法}

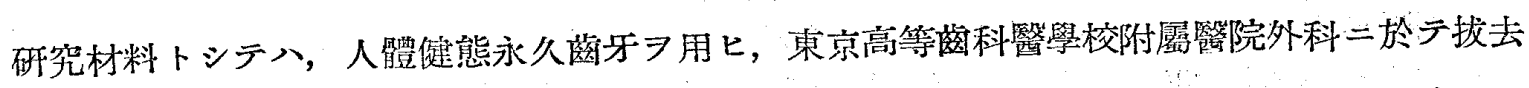

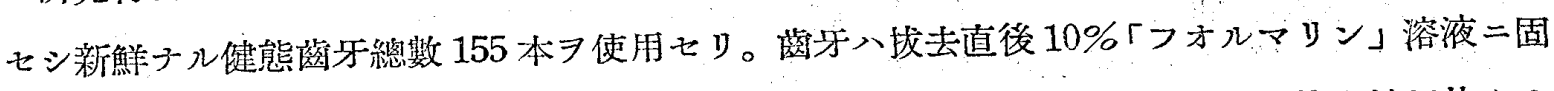

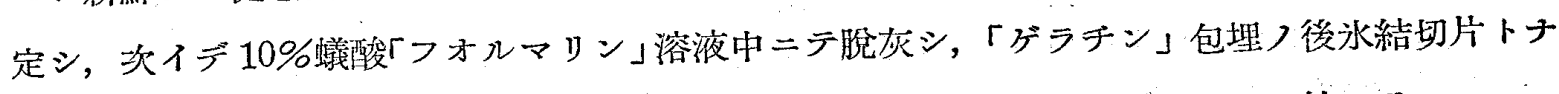

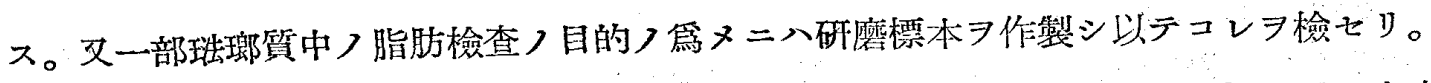

脂肪ノ染色法トシテハ川村，矢崎氏(4)(5) 「アルコール」「ズダン」目トニョル染色习併用シ，以テ兩者つ成績 


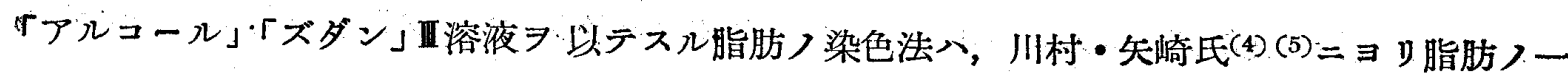
新染色法トシテ創製セラレタルモノニシテ，本法入在來ノ70\%「アルコール」ズダン」目溶液つ. 代リ $=40 \%$ 「アルコール」溶液 シ到底比較シ難キ程度二於テ多量二出現セラルルモノナリ。コレ70\%「アルコール」溶液二於 テハ脂肪ノ或儿種類八不尠量二於テ溶解沿失七ラルルモ, $40 \%$ 於テハソノ溶解度甚ダ低下ス ルガ爲メナリ。今ソノ40\%「アルコール」ズダン」溶液二就キ簡單二述プレバ次ノ如シ。

本液ハ在來つ70\%溶液トハソノ調製法湴二性狀习全ク異ニス。本液ハコレラ基本液及ビ染色

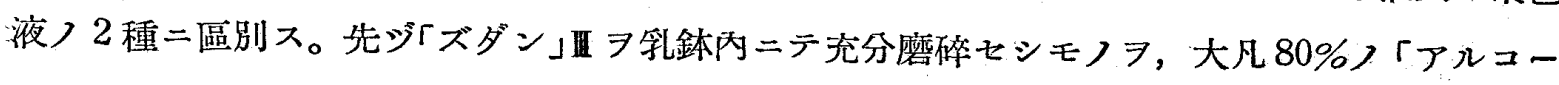
ル」溶液二テ處置シ, 茲二暗赤色透明ナル溶液习得。コレア基本液卜稱ス。コク基本液 $50 \mathrm{cc}=$ 蒸餾水 七ル膠樣狀液 (40\%「アルコール」溶液) 7 得。本液 $习$ 染色液ト稱ス。基本液八可成長期間保存 シ得ルモ, 染色液八甚ダ變化シ易ク數日間使用シ得ル二過ギザルモつナリ。染色二際シテハコ ノ染色液中二切片ア入レ, 攝氏 $29-30$ 度つ孵卵器內二約 5 時問留置スルモ)ナリ。(本法)詳 細入東京醫事新誌第 2823 號及ビ第 2867 號，川村・矢崎氏「脂肪ノ一新染色法」及ビ「再ビ余 等つ脂肪新染色法站ニソノ基本液作製變法ニ就デラ參照アリタシ)。

又全例二就キチャチォ氏染色法ヨ行ヒ本染色二於テモ 70\%及ビ 40\%) 兩「ズダン」染色法

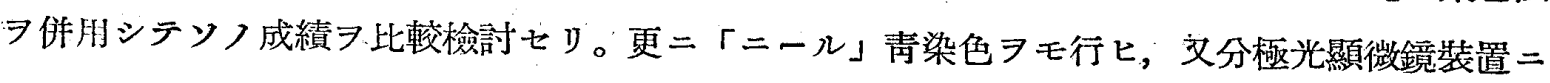
依リ，脂肪ノ重屈折性二就ギテ檢セリ。爾後本文二於テハ川村・矢崎氏 $40 \%$ 「アルコール」ズ

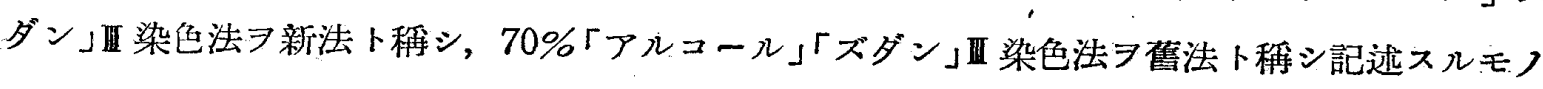
小的。

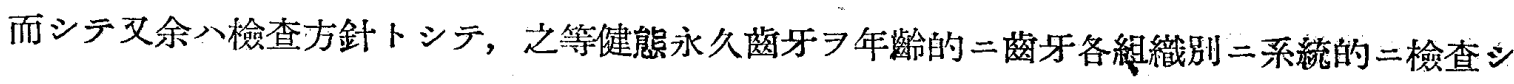
以テ年齡二由ル萄牙脂肪浸潤 牙脂肪出現つ時期二如何ナル關係习有スルモノナルカラ比較檢討セント欲セり。コノ目的ノ爲

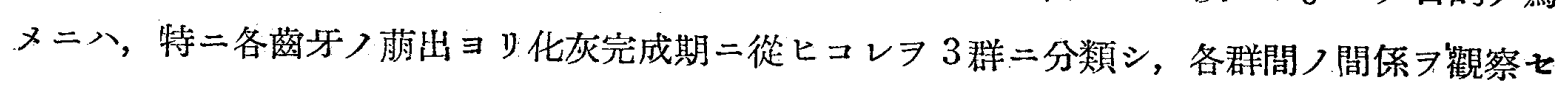

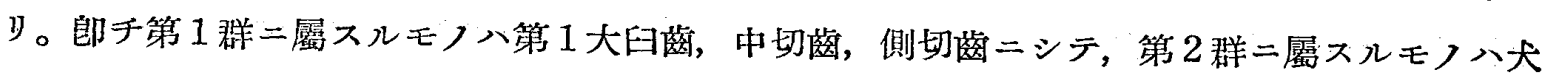

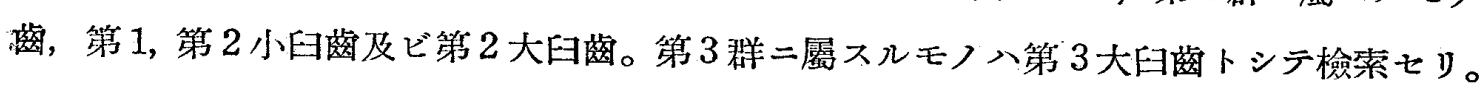

\section{第 3 童 研究成 績}

健態永久苜牙二於ヶル脂肪ノ消長 7 檢センニ八，胎生期ヨリ老年期ニ及ブ各年代二於ヶル各 蒛牙二就キ，確實ナル組織的檢甞习行フヨ必要卜ス。余八既二述べタルガ如ク，研究材料トシ

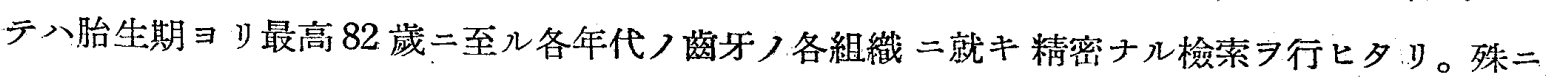

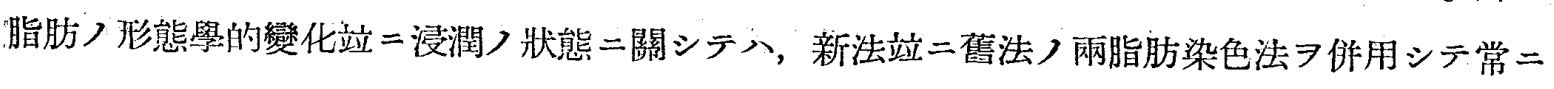


コノ兩者つ成績 $コ$ 比較觀察スルコトト七リ。以下各組織二於ケル成縝ノ詳細 フ綜合的所見二就キ詳述スルコトトセリ。

第 1 編 泆瑯質脂肪所兒

理瑯質ハ人體中二テ最モ硬固ナル組織ニシテ殆ンド石灰分ヨリ組成セラレ，ソノ檢菜ニハ單二研磨標

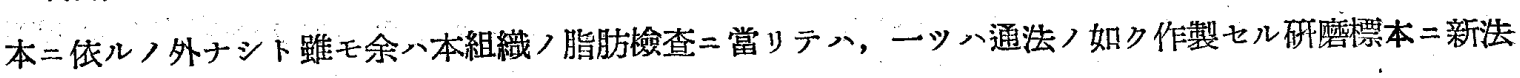

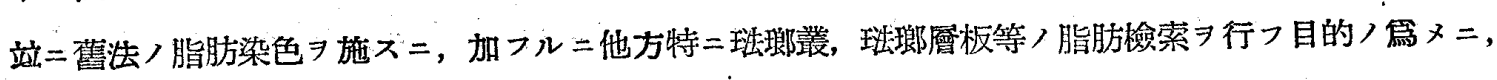

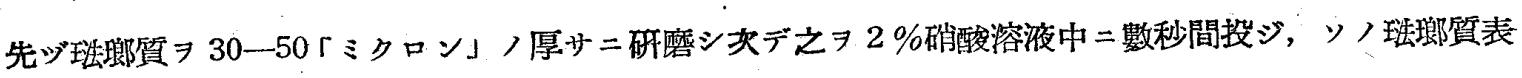
面)稍々溷濁スル迄作用セシメ，直チ二切片 $ヨ$ 取り出シ、コレヨ滅菌蒸溜水中二テ水洗ス。斯ク操作七

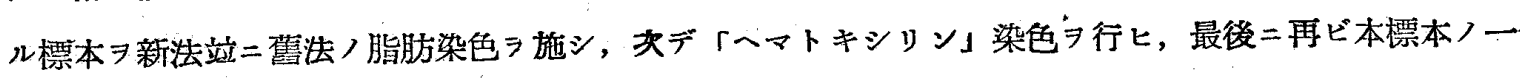
側面 $\exists$ 研硡シ，水洗セル後「グリセリン」包埋ノ上檢镜セリ。

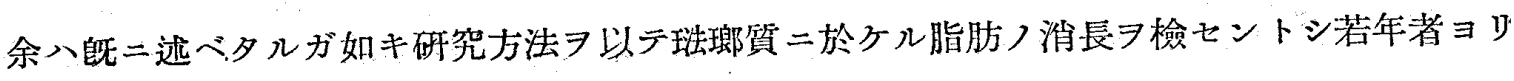
高年者二及プ兴牙 35 例二於テ檢查 17 例二新法ノミノ脂肪染色习施シコレヨ檢セり。萑法习以テ染色シ檢索セシ各例二於テハ全ク

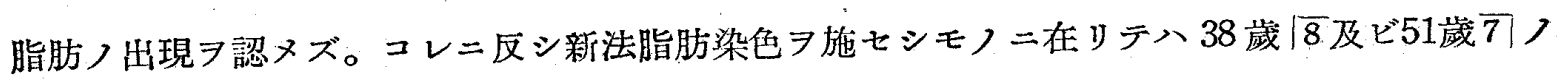

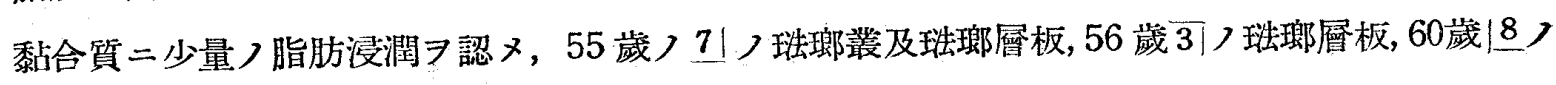
昢瑯叢二脂肪浸潤习認メ得タリ。コレ等新法染色ニ由リデ得ラレタル脂肪ノ所見八間質二於テ

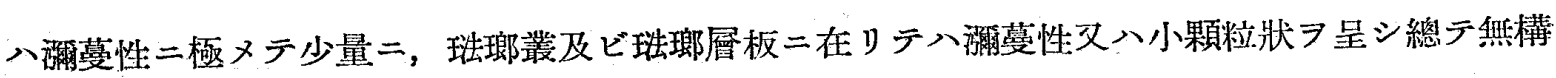
造帶黃橙色习呈そり。

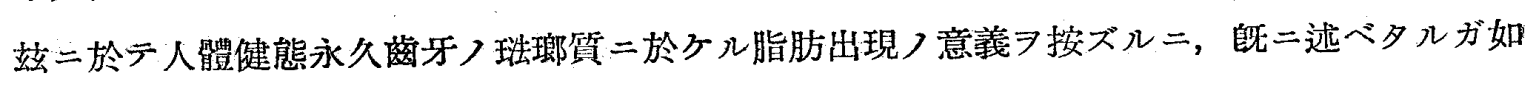
ク珗瑯質夫レ自體ガソノ組成人體組織中最モ硬固ニシテ, ソノ檢索二八研磨標本二訨ルノ外ナ ク從ツテ構造つ詳細

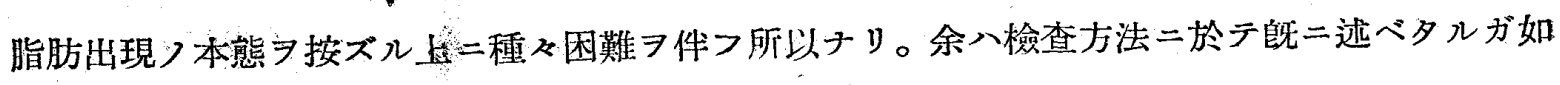
ク，2種つ研磨標本 $\ni$ 作製シ可及的詳細二檢索セシ結果入可檢總數 35 例中, 舊法ニテ八脂肪ノ

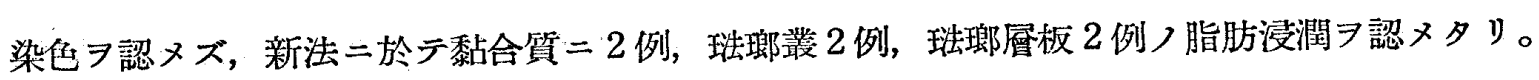
中村氏(11)八健態永久齿牙珠瑯質二於テハ, 昢瑯質つ各組織二脂肪浸潤习認メズト述ベタリ。赤 松氏 (31) ハソノ少數例二於テ斑瑯質二一定ノ變化习認ムルモ大多數二於テハ脂肪习認メズ。氏 ハコレ等珠瑯質二於ケル脂肪浸潤八，外的二口腔內食物二由來スル脂肪浸潤ナリト認メタリ。 又國分氏 ${ }^{(3)}$ 八 Romeis 法二由リ泆瑯質ノ脂肪染色 肪浸潤つ來ルラ認メ，コレ等珄瑯質二認メラルル脂肪浸潤入外的二食物中ノ脂肪ノ浸潤二由來

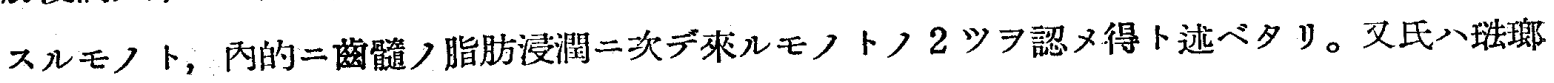
灇二脂肪浸潤ノ認メラレタル例二於テ同時二秥合質二モ脂肪浸潤ノ出現セシ事實ヨリシテ, コ

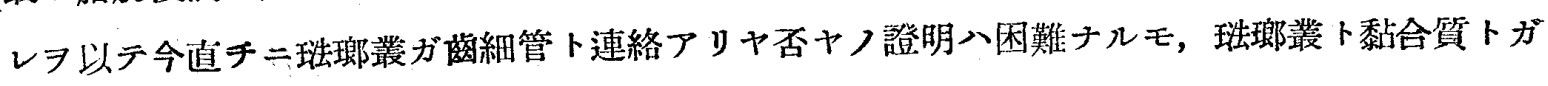


少クトモ同物質ヨリ成立スルコトラ想像シ得ルモノニシテ, コレガ人工的產物ニ非ザルコトヨ

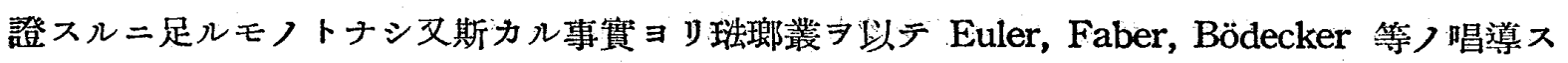
ルガ如キ珐瑯質へノ淋巴榮飬道卜思考シテ可ナラントセリ。角田・伊藤兩氏 (20)八舊法染色二 依儿時八極ク稀レニ泆瑯紡錘內二微細顆粒トシテ脂肪习認ムルニ過ギザルモ, Romeis 法及ビ

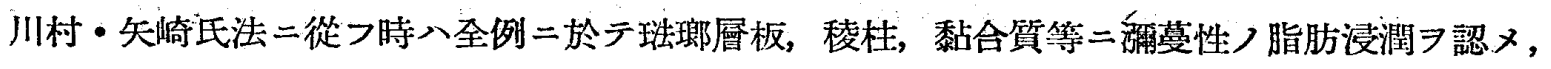

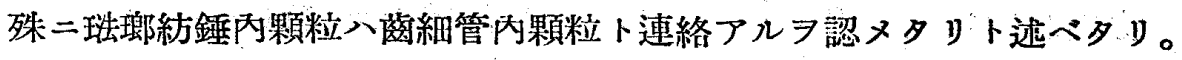

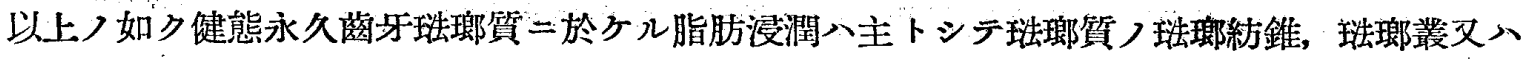
珠瑯層板等二認メラルル所見ナり。

珐瑯質二於万ル脂肪浸潤ノ由來 $\exists$ 大別スル二外的二食物內脂肪ノ浸潤ノミニ由ルト見做スモ

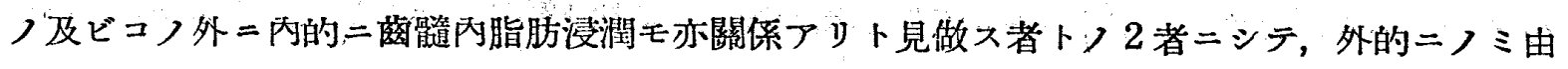

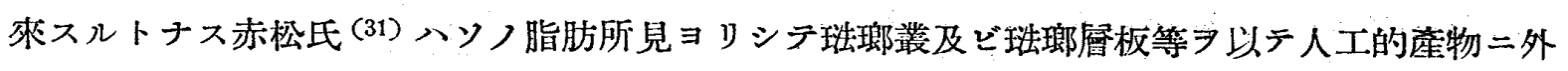
ナラズト見做セリ。コレニ反シ國分氏 ${ }^{(3)}$, 角田・伊藤氏 (20) 等八外的

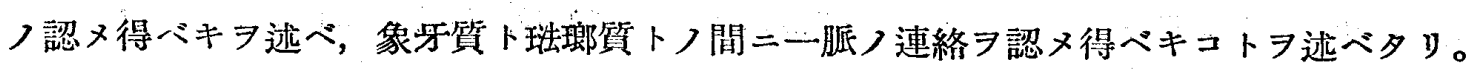

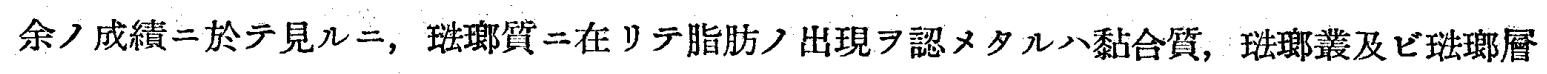

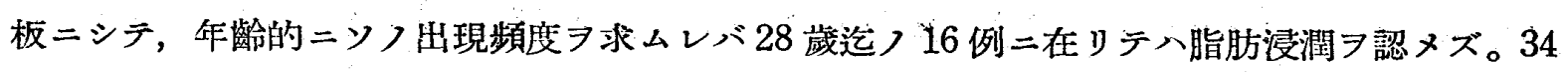

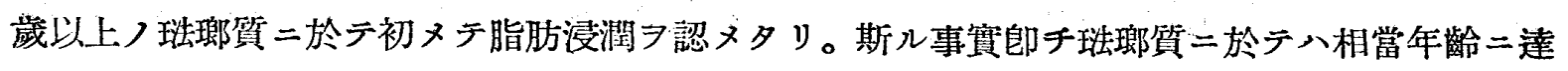

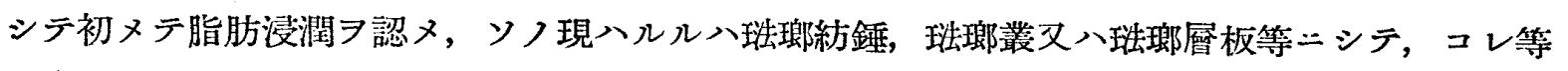
八象牙質二接近シテ存在シ象牙質, 耖瑯質境界ヨリ起始ス几正常構造ノ一ナル事實ヨリ, 象牙

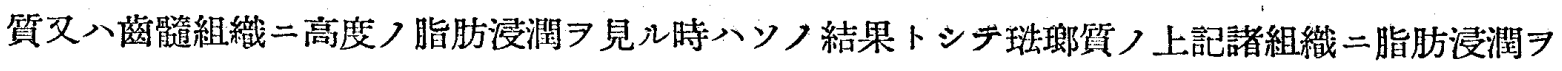
生ジ得ベキモノナリト解シ得ベシ。

第 2 編象牙質脂肪所見

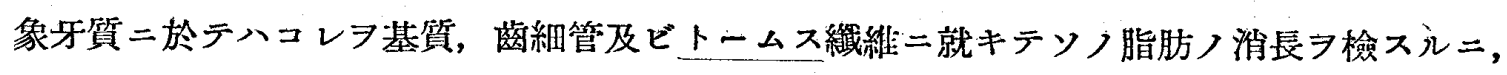

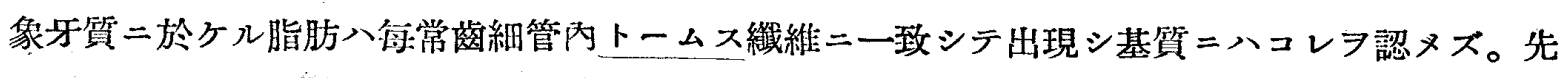

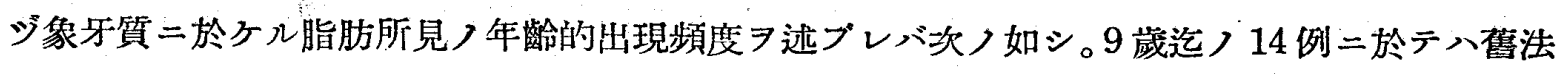
新法共二總テ脂肪 7 認メズ。10歲ヨリ19歲迄ノ16 例中 6 例 二於テハ新法二テ觜細管內上一

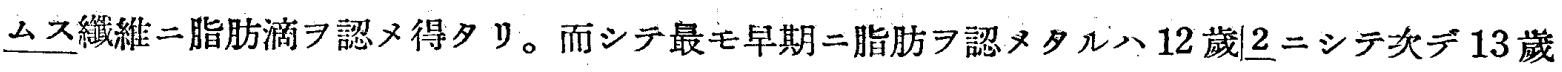

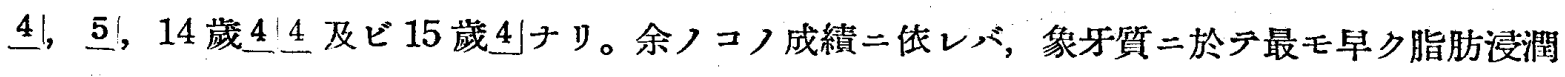

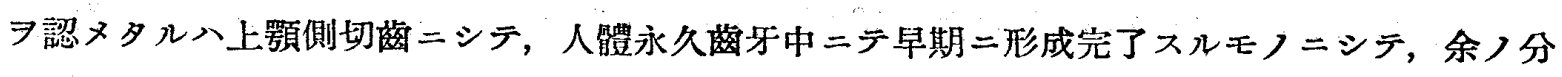

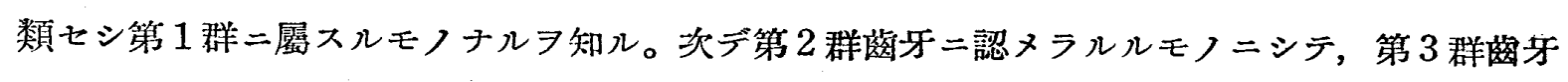
二於テハ一部既二萠出

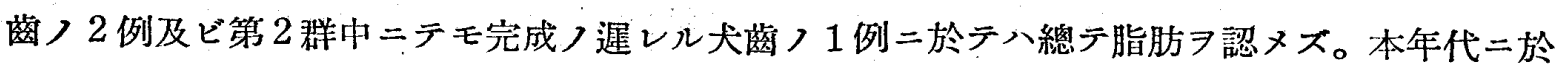

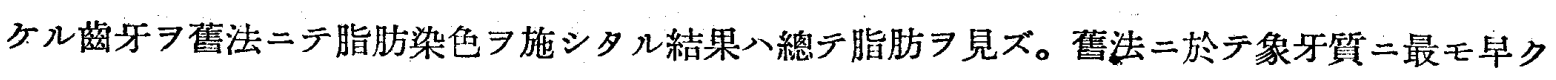


脂肪习認ムル入, 余八 27 歲, 中村氏(11)八 26 歲ニシテ, コノ成績卜余ノ新法染色ニヨル成績 ヨ比較スル時八新法二於テ像牙質二著シク早期二脂肪习認ムルコトヨ知ル。

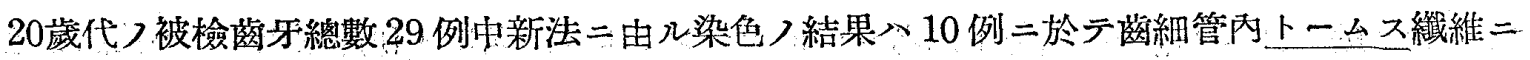

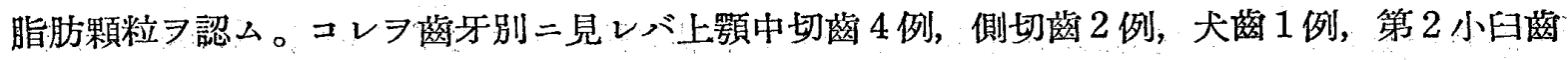

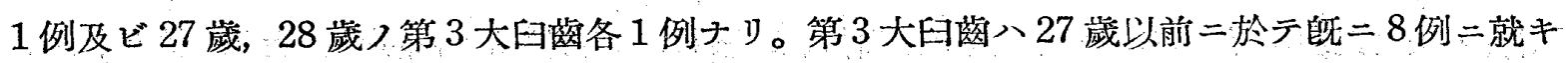

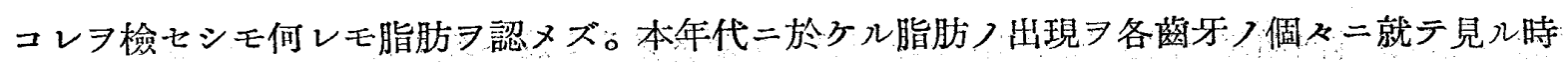

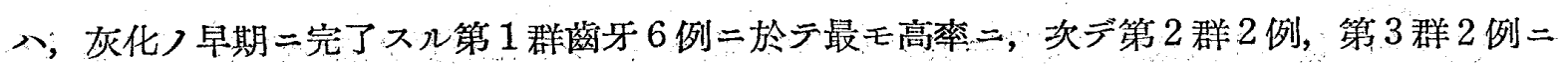

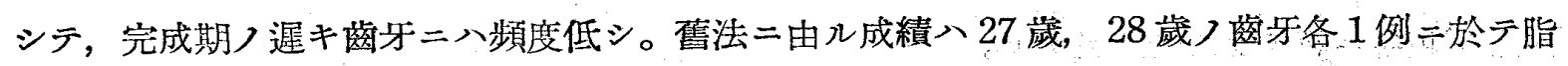

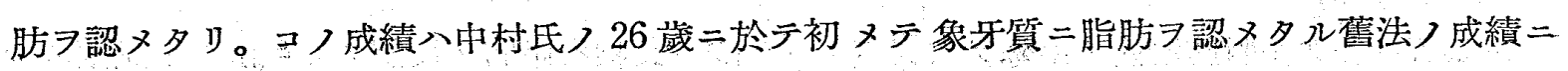
略々一致ス儿所見ナリ。本年代二於テ脂肪出現頻度习新法ト舊法卜ニテ比較觀察スレバ，新法 ニテ $34.5 \%$ ニシテ, 舊法八僅カ二 $6.9 \%$ 二過ギズ。

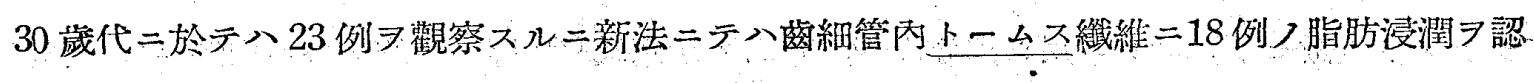
メ，舊法ニテハ 8 例二認メタリ。 コレラ莮牙别ニスレバ第 1 群，第 2 群二在りテハソノ差異比 較的輕少ナレドモ，第3群二於テハ出現率甚ダ低ク 34 歲及ビ 36 歲ノ各 1 例二於テ新法ニョリ 少量二認メタルモノニシテ，30歲及ビ 37 感つ 2 例二於テ八浸潤习認メズ。本年代二於ケル脂 肪出現頻度つ新法及ビ舊法つ比較八新法 $78.3 \%$, 舊法 $34.8 \%$-シテ新法入約 2 倍つ出現率 중

40 歲代 15 例二於テ八新法二テ 14 例，舊法ニテ 12 例二脂肪浸潤 7 認ム。而シテ本年代二

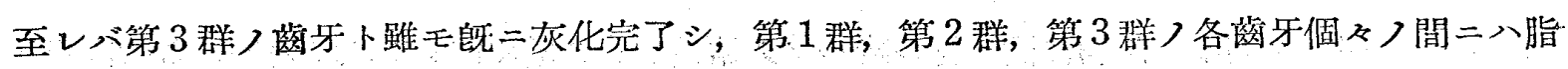

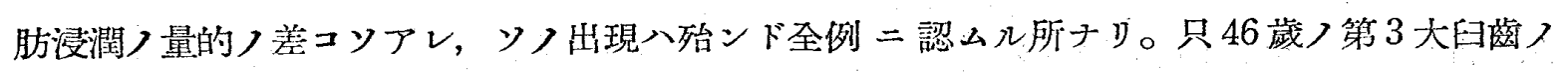
1 例二於テ茼木新法, 舊法共二陰性つ結果 肪出現頻度习新法, 舊法ニヨ! 比較スレバ, 新法 $93.3 \%$, 䳡法 $80 \%$ 二シテ兩者, 殆ンド同様ナ ル成績ヨ示ス。

50 歲代 21 例二在りテ八新法二テ21例, 舊法ニテ16 例つ脂肪浸潤习認山。本年代二至レ バ各蒛牙共二頗儿著明テル脂肪滴つ存在 ザルニ至ル。而シテ新法及ビ舊法二由ル脂肪出現つ頻度つ差異モ殆ンド認メ得ザル程度ナレド 出現量二於テ八新法八舊法二比シ甚ダシク著明ナリ。

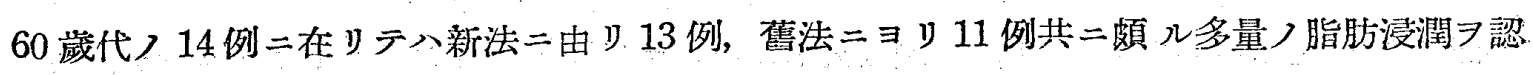
厶。

70 歲代 8 例二於テ八新法二テ 8 例, 舊法二テ 7 例二共二多量つ脂肪浸潤习認メタリ。

80 歲代 2 例二於テモ亦新, 舊兩法二由リ多量つ脂肪浸潤习認么。以上述べタル象牙質つ內

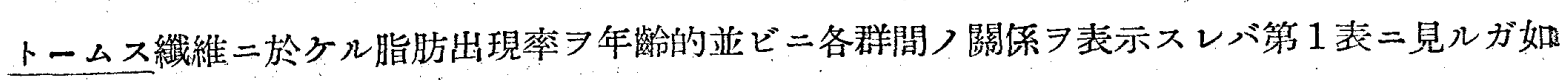




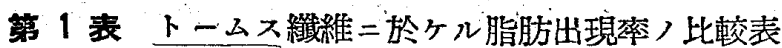

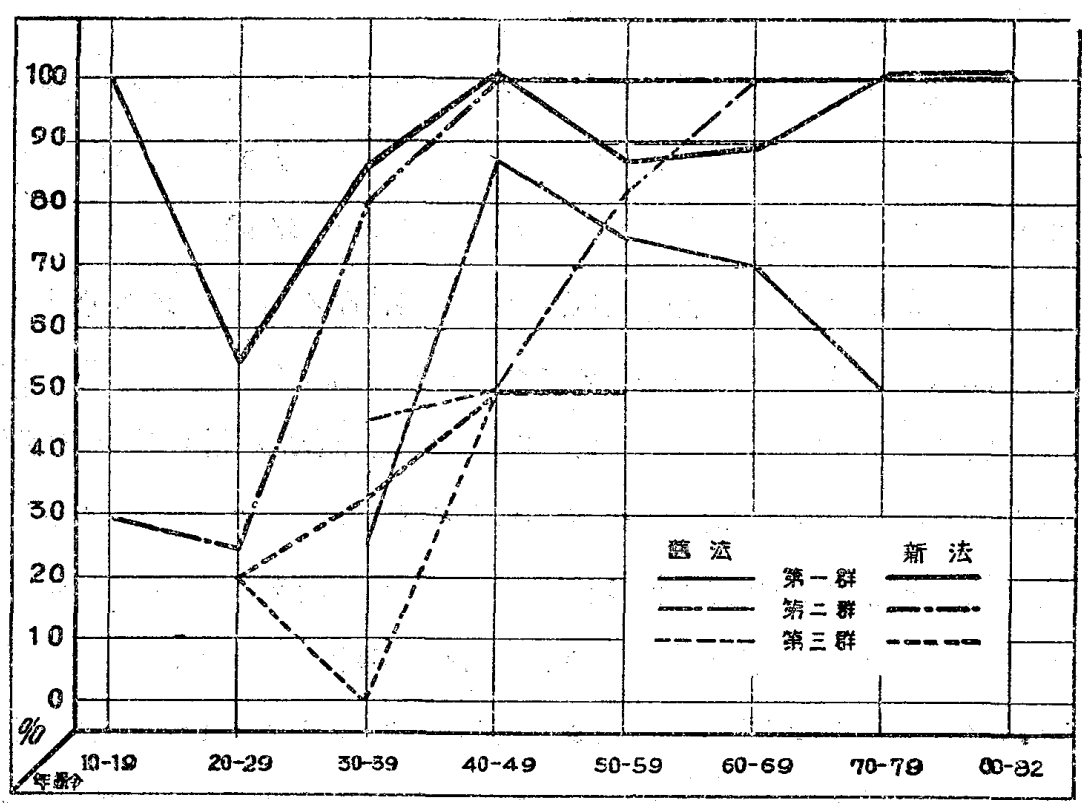

象牙質內ノトームス纖維二一致シテ出現スル脂肪ノ形態 徵細ナル圓形, 牛圓形, 指輸狀文稀レニ桿狀习呈スルモノナリ。新法二由レバ美麗ナル大小ノ 滴狀 7 呈ス。

色調八舊法ニテハ主トシテ暗赤褐色 二脂肪浸潤著明于ルモノニテハ美麗ナル大滴狀

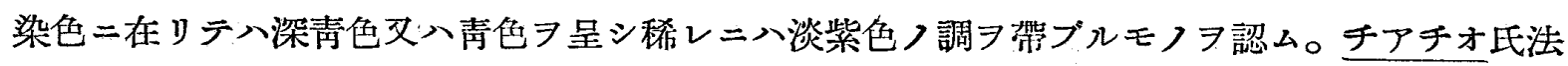
ニ由レバ舊法染色二テハ黄褐色, 新法染色ニテハ赤褐色

是习分極光裝置下二檢スレバ單屈折性ニシテ重屈折ヨ呈セズ。是等種々ナル反應ヨ綜合シテ 本脂肪つ性狀ハ「リポイド」二屬スベキモノナリ。

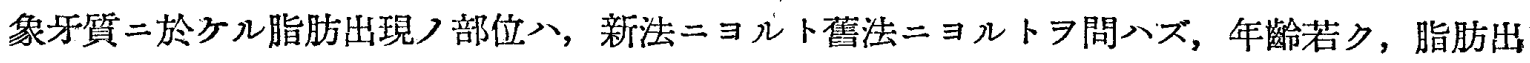

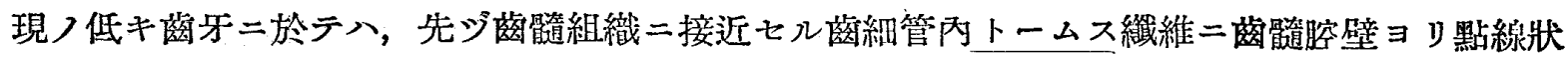

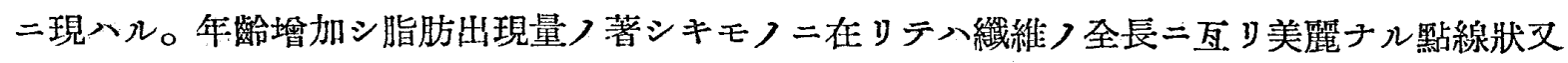
八線狀 $尹$ 呈シテ出現スルニ至ル。

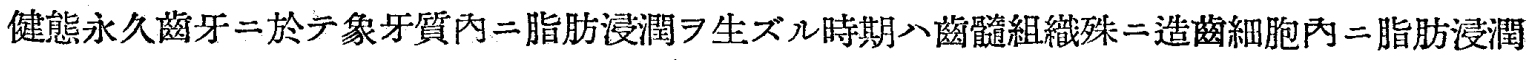
ノ現ヘレタル後二於テ出現スルラ常トシコレ象牙質苳細管內二出現スル脂肪質ハト一ムス㵶維

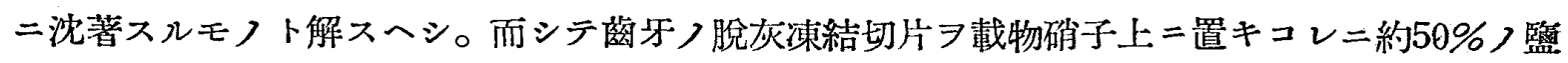
酸又八硝酸习滴下シ少シク加溫スル時八，基質八次第二溶解シ逐ニトームス緎維ノミ残存スル

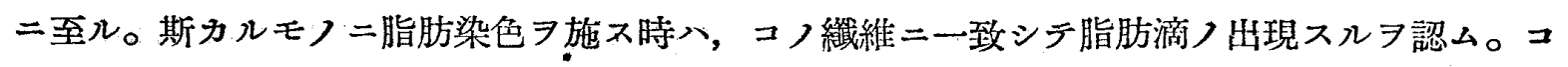




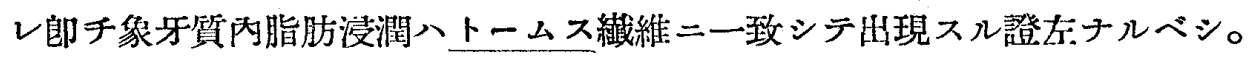

象牙質二於ケル脂肪染色つ成績八，新法二由ル場合八䳡法二由儿場合二比較シ囬ダシク著明 ニシテ且ツ美麗ナル成績フ是ス。

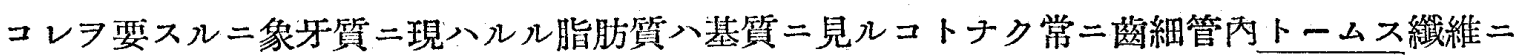

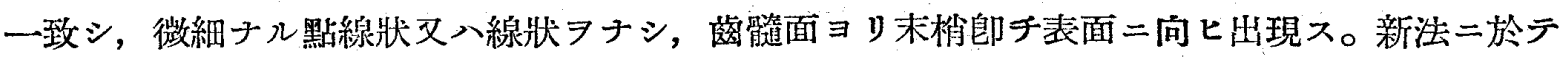

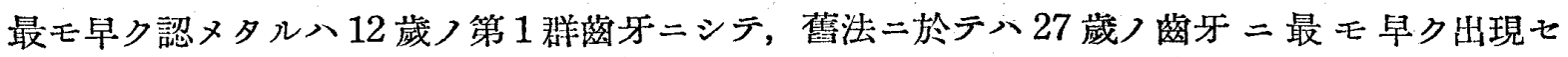
リ。新法二於アル成績八鹤法二比較シ酺ダ顯著ニシテ, 兩者ノ出現率 $\ni$ 百分比二求ムレバ, ソ ノ差入若年者二見儿程著明ニシテ 20 歲代二於テハ新法入舊法つ約 5 倍, 30 歲代二於テハ新法 八舊法ノ約 2 倍二出現ス。而レドモ 40 歲以上ニ於テ八新舊兩法つ間二殆ンド相異习認メズ, 單 二出現量二差习見ルノミ。脂肪ノ種類八種ぬナル反隹习綜合スルニ「リポイド」二嵹スルモノ

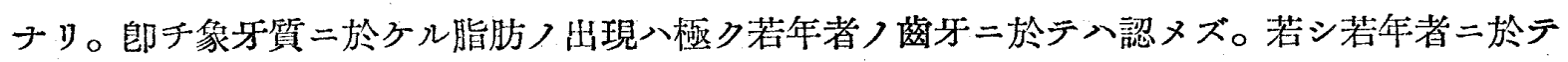

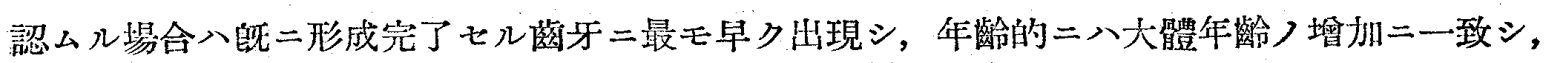
又苳牙個々二於テハソノ形成期ノ順序二一致シテ出現习見ルモノナレド，ソノ出現ノ意義二關

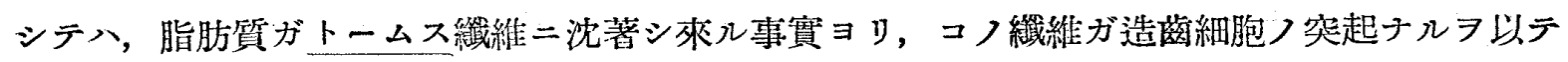

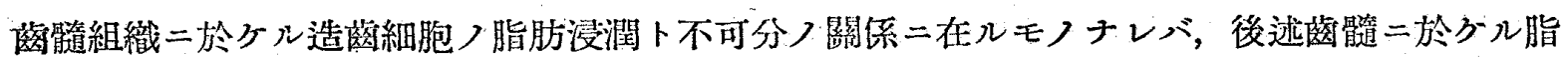
肪所見ノ編二於テ詳述スベシ。

第 3 編 白壁質脂肪所見

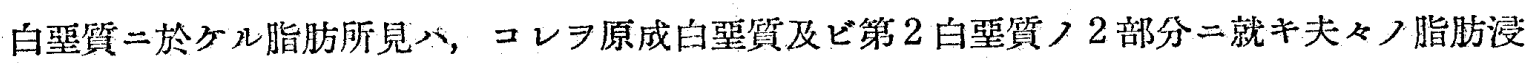

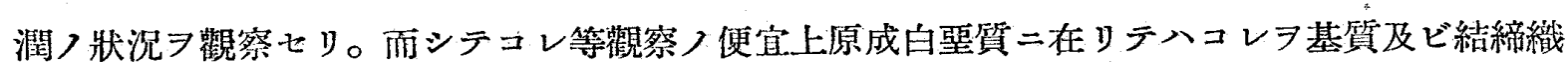
緎維，第 2 白旺質二在リテハ基質，小窝及ピ白監質小體二就キソノ脂肪浸潤ノ狀態

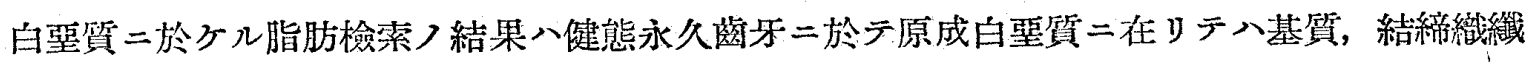
維共二脂肪浸閵习認メズ。第 2 白壁質ニ在りテモ基質二八脂肪浸潤ナシ。

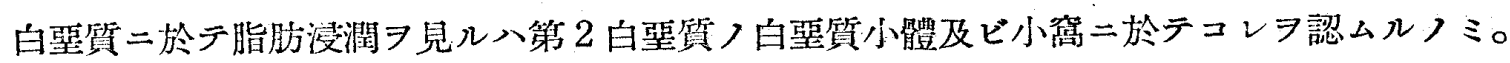

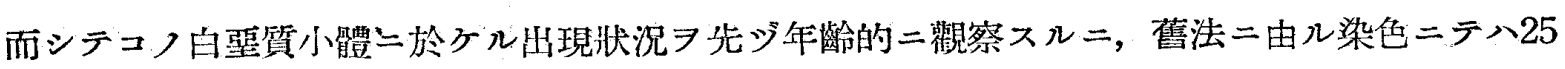

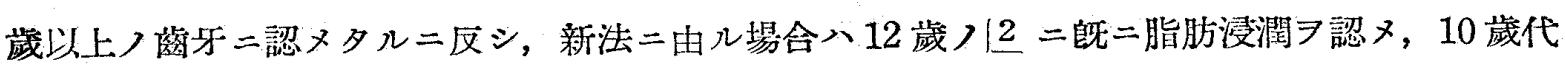

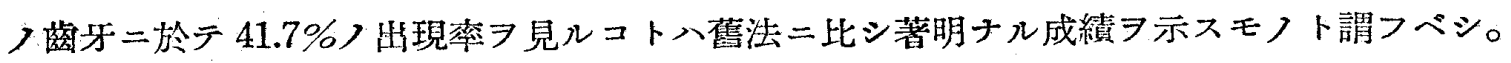

20 歲代ノ 29 例二於テ, 舊法入 $21.4 \%$ ナル比シ, 新法八 $57.1 \%$ 示シ, 30 歲つ 23 例二在

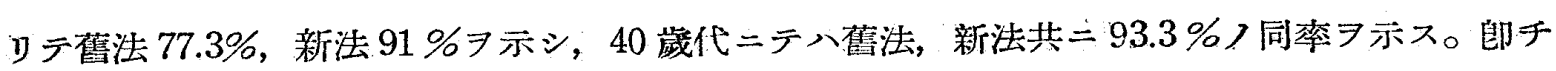

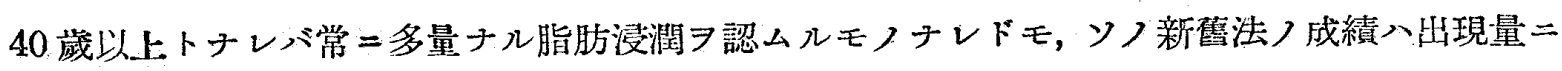
於テ新法八遙カ二多量ナルラ示セリ。

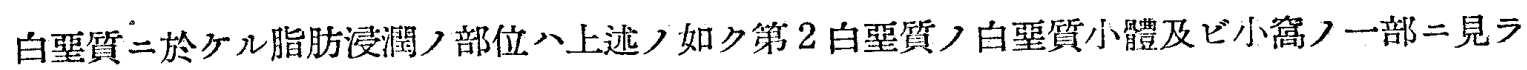

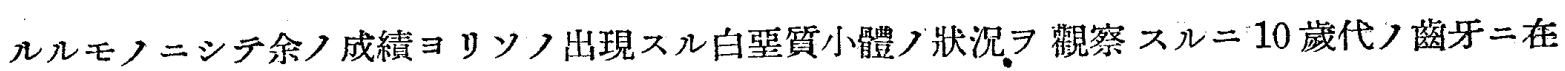




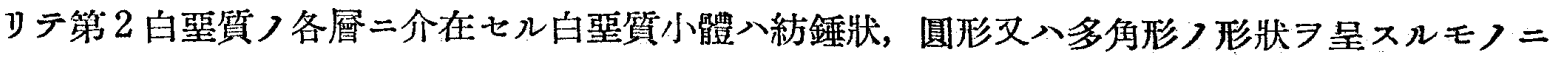
シテ夫等ノ內二於テモ又核ノ大ナルモノ師チ幼若ナル小體二於テハ脂肪漫潤习認ムルコト稀二 シテ, 多クハ核ノ泡狀ヨ呈スル小體又八核ノ小ナルモノニ於テ脂肪浸潤习認メタリ。脂肪ノ形

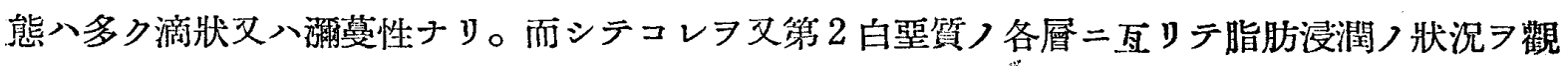

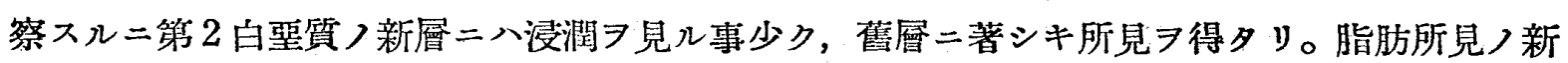
法及ビ舊法二依儿成總ノ此較八新法八遥カ二舊法ヨリ著明ナル成續习示シ, 染色スル色調八舊 法ニテハ淡黄褐色，新法ニテ八美麗ナル橙赤色 由裂質ノ新舊，中間層二介在スル核ノ小ナルモノ又八核ノ泡狀 二脂肪浸潤习認ムルモ，新層內二介在スル核ノ大ナル白型質小體二於テ八脂肪浸潤习認メザル モノ多シ。然レドモコレ等新層卜踓モ層內二介在スル核つ小ナル白壁質小體, 又八核ノ泡狀习 呈スルモノニ在リテ八，舊層又八中間層二見ルト同樣二脂肪浸潤习認ム。脂肪ノ形態八本年代 二於テ八核ノ周圍二或八塺埃狀二或八滴狀二又八做蔓性二來》，色調八鹤法染色二由リ褐色又

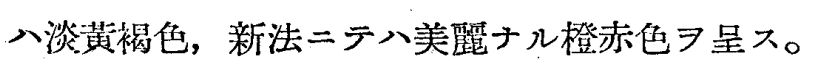

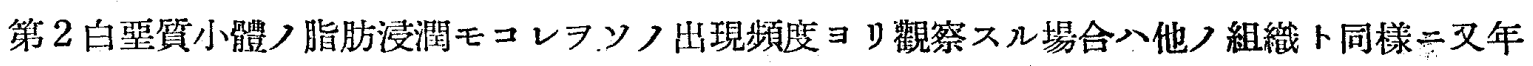

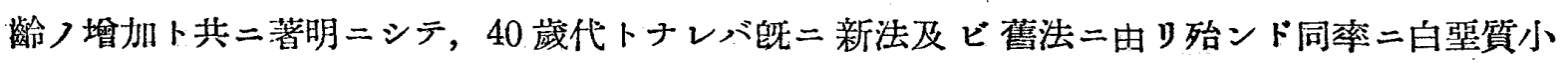
體內二脂肪浸潤习認メ比較的脂肪出現ノ稀ナル圓形 出現习認ムルニ至ルモノナリ。

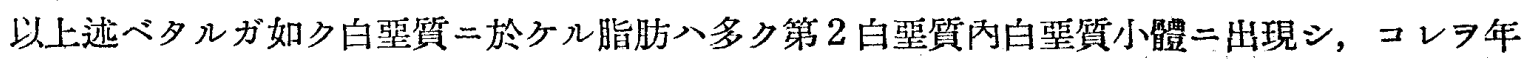

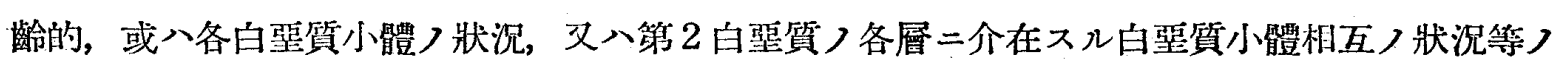

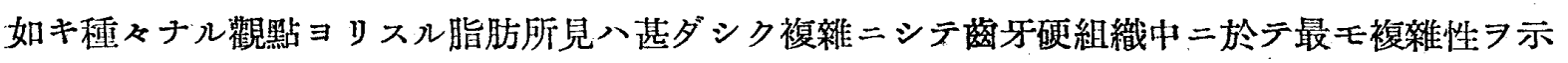

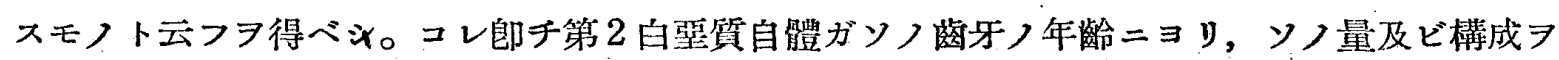
異ニスルノミナラズ, 周圍ノ環境ニョリ複雜ナル變化ヨ示ス $ヨ$ 以ソノ脂肪浸潤ノ狀況モ亦コ レ等ノ狀態二關聯シテ種ネナル變化ヨ示スモノナリ。

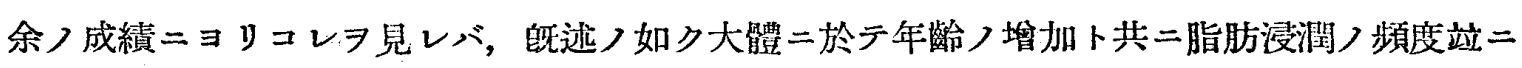
量つ增加习認ムレドモ, コレモ比較的ノ問題ニシテ, 脂肪浸潤つ狀況八第 2 白琹質ノ種類, 性

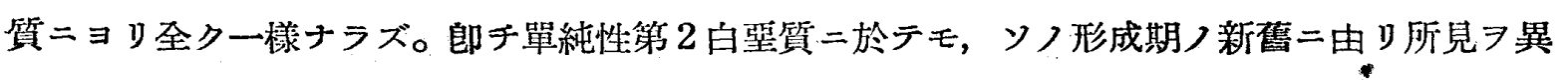

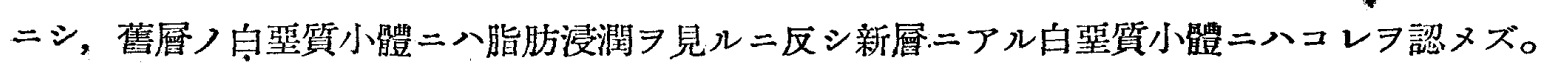
又吸收型或入白型質瘤ニ至りテハ後述スルガ如キ一層複嚾ナル脂肪所見习呈スルモノナリ。

又白䜿質小體つ形態二由リ，脂肪浸潤ノ狀況ガ異ナルコトモ上述ノ如クニシテ，一般二圆形 ヨ呈スルモノ二少量二, 紡錘形入八多角形フ呈スルモノニ多量二脂肪浸潤习認メタリ。コレ等 脂肪ノ色調八新法二在リテハ多ク美麗ナル橙赤色 $コ$ 呈シ, 舊法二於テハ褐色又、淡黄褐色

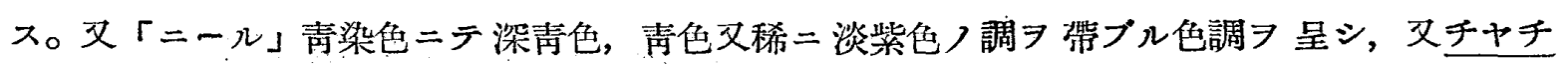


オ氏法二由レバ，新法染色二由り赤褐色，舊法ニヨリ黃褐色

脂肪ノ形態入多ク滴狀又八籋蔓性:示スモノナリ。

以上つ如キ種ふナル脂肪ノ性質ヨリシテ脂肪ノ種類入象牙質二於らルト同樣「リポイドニ 屬スルラ知儿。

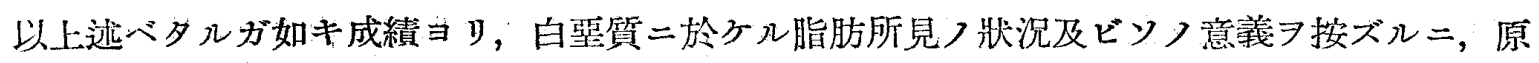
成白堊質二八脂肪浸潤

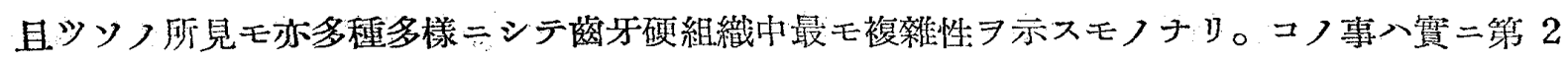
白峛質つ形成つ複雜性二起因スルモノナルベシ。元來第 2 白壁質八間歇的二堆績スルモノニシ

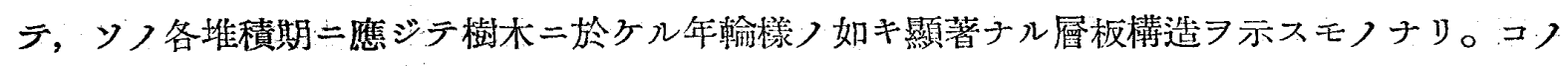

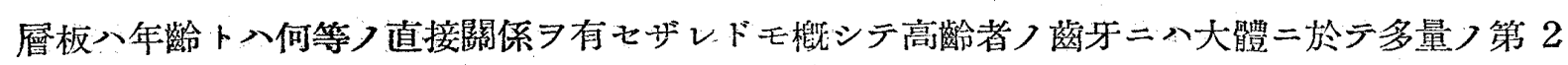

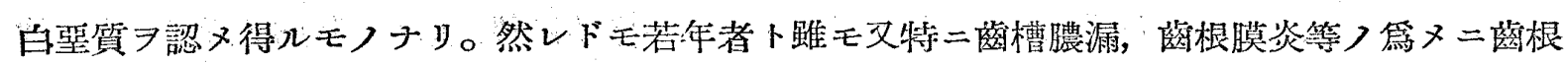

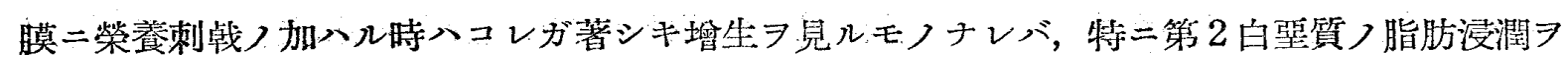

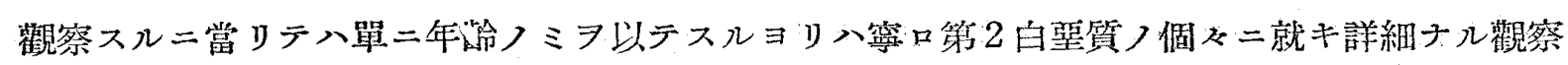

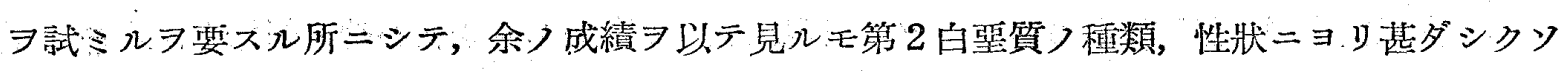

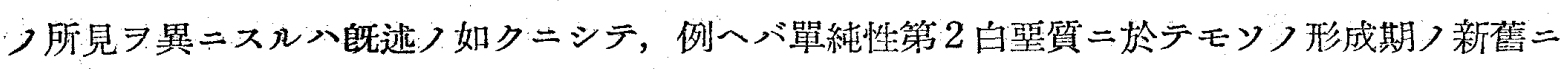

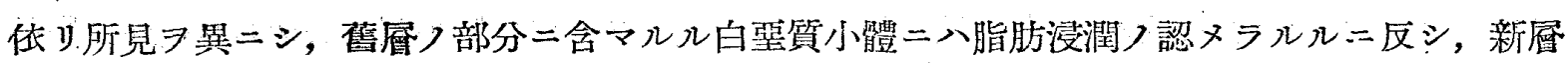

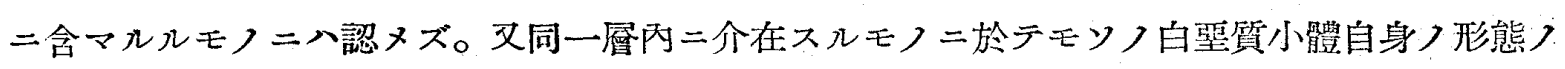

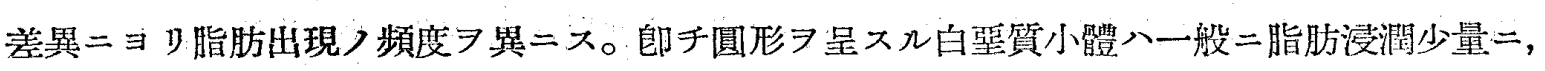

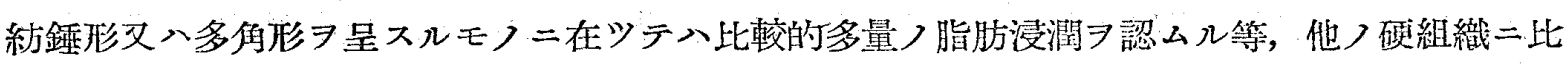

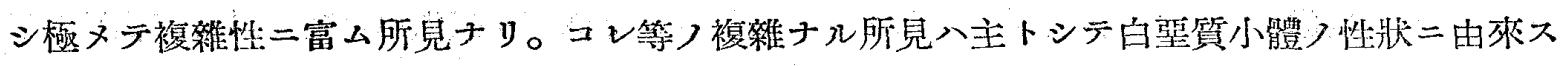

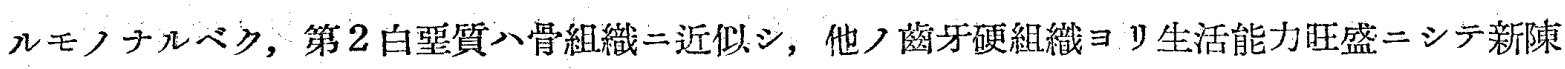

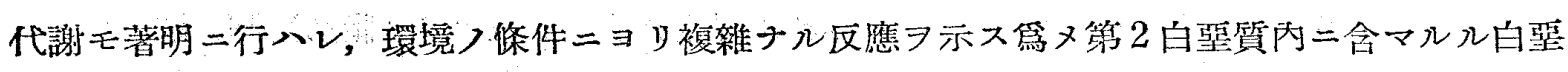

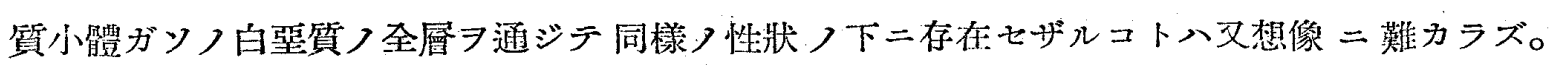

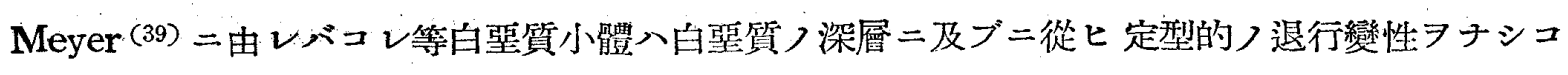
ノ變性八細胞核及ビ細胞體ニモ發見セラレ次第二變性萎縮シテ逐二死滅スルニ至ルモノナリ

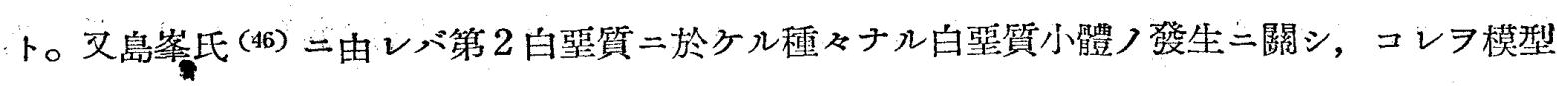

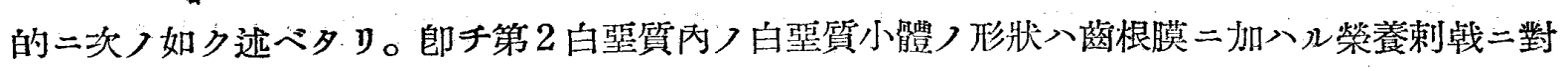
スル結締織細胞ノ態度二由ルモノニシテ, 氏ハコレラ大體ニ於テ 3 型二區別セり。第 1 型入狹

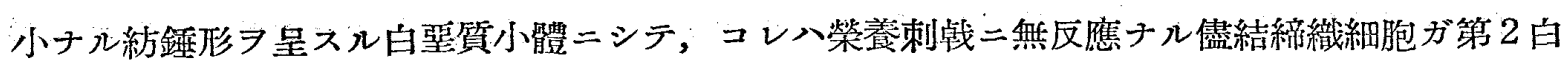

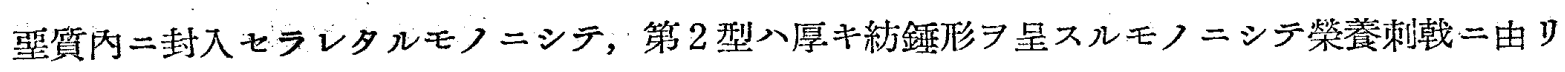

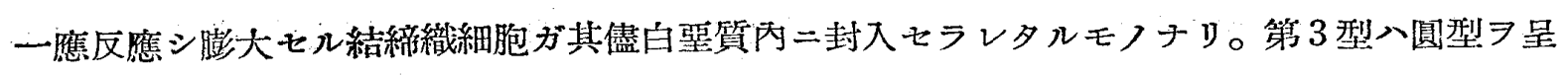
スル白旺質小體ニシテ榮養刺钱二反應シテ結締織細胞ガ膨大シ造白琹質縕胞トシテノ活性ヨ帶 
ビタルモノガ第 2 白恶質內二封入七ラレタルモノナリト述ベタリ。而シテ斯クつ如キ所見二從

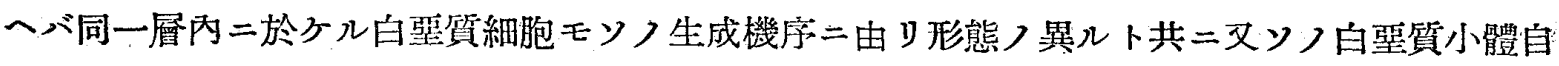
身ノ活性二モ一定ノ異差习認ムルハ當然ノ事ナルベシ。コレニ加フルニスコレ等白壁質小體が 前述ノ如ク骨小體ト同ジク定型的ノ退行變性アナシ逐二死隇スル場合入第 2 白堅質內二單二窩: 洞トシテ白型質小㸗フ認ムルニ過ギザルニ至ルモノナリ。

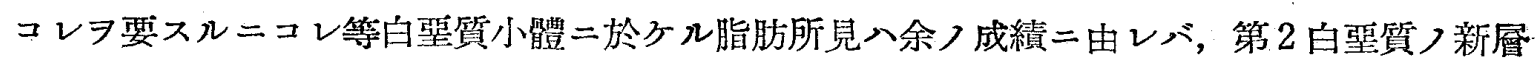

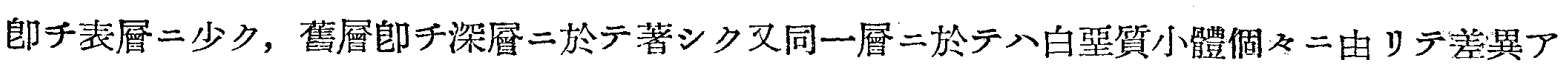
》，圓形ノモノニ少ク，紡錘形又八多角形ノモノ二著明ナリ。是等つ白惡質小體つ變化ト脂肪

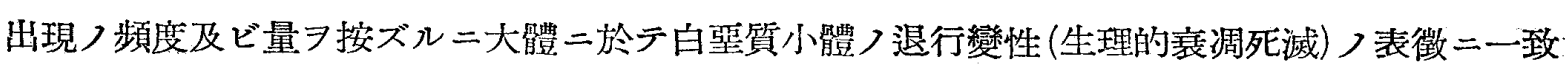
スト云フラ得ヘク，コレ等ノ所見ヨ規蕉トシテ考察スル時八，複雜ナル第 2 白堅質つ構造モ亦

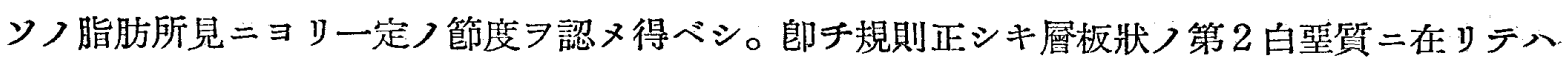

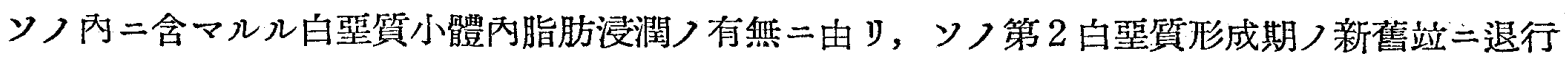

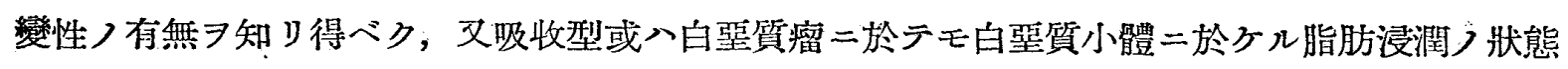
ニ由リソノ複雜性习想像シ得ベシ。吸收型二於テソノ一部ニ於テハ白堅質小體二脂肪浸潤习認 メ，他ノ部分ノモノニ浸潤习認メザル場合アリ。斯カル場合ハコレ師チ吸收セラレタル第 2 白

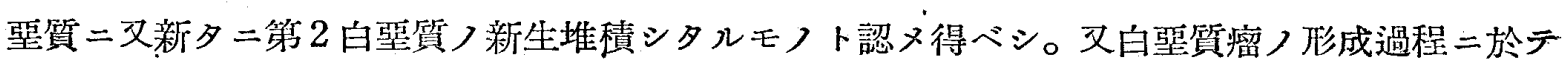
モソノ脂肪浸潤ノ狀況 ニョリ白堅質瘤形成狀況ノ機序习想像シ得ベシ。

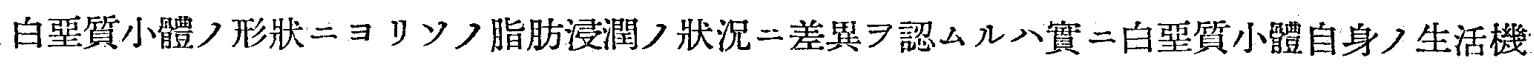
序ヨ知り得ルモノニシテ，斯カル種くナル所見习綜合シ觀察考究スル時八苳根膜ノ性狀及ビ固

第 2 表 白㤠質小體ニ於ヶル脂肪出現率 比較表

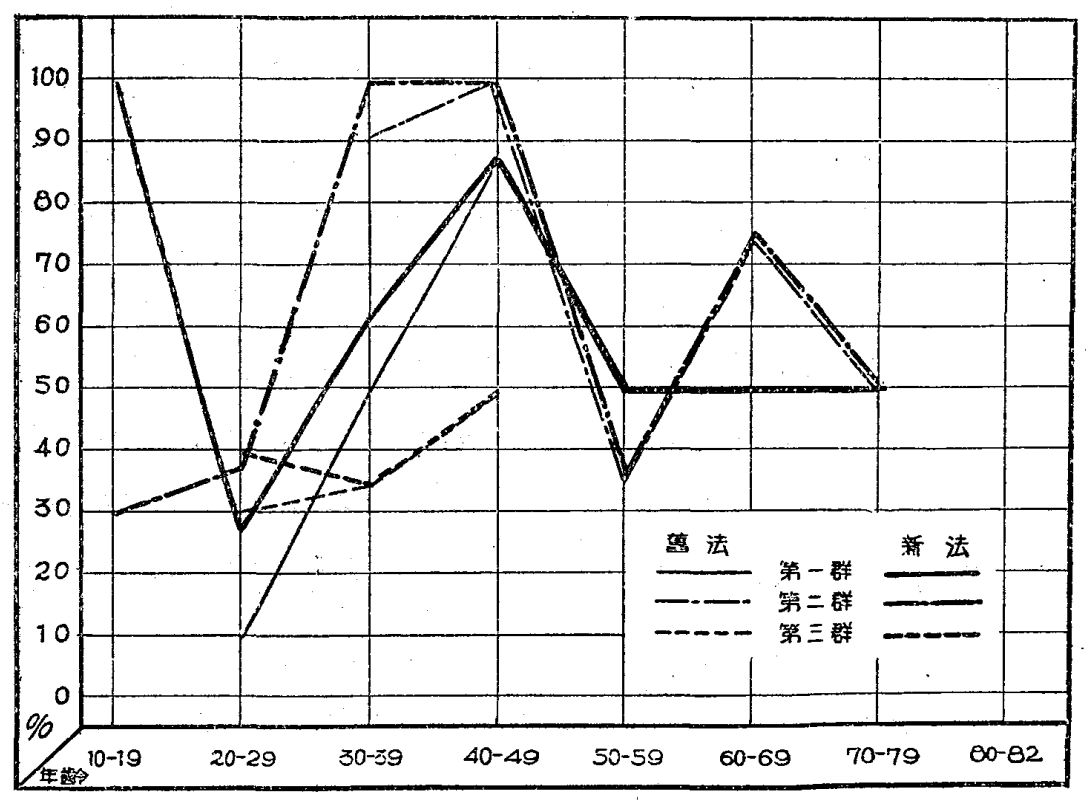




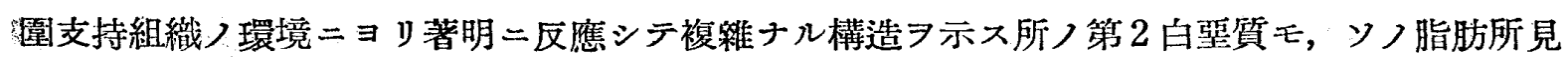

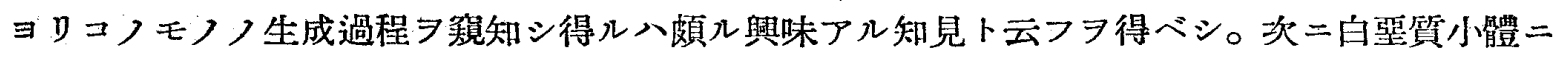
於ケル脂肪ノ消長习表示スレバ第 2 表ノ如シ。

第 4 編 齿髓 脂肪 所見

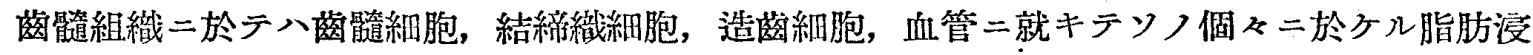

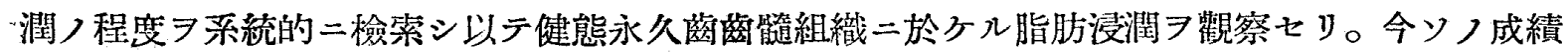
ヨ述ブレバ次ノ如シ。

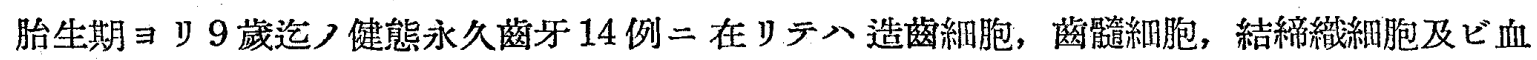

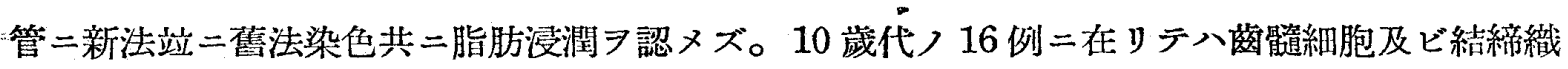
細胞八共二脂肪浸潤ラ認メザレドモ造苳細胞二在りテハ舊法ニテ 4 例, 新法ニテ 13 例ノ脂肪浸

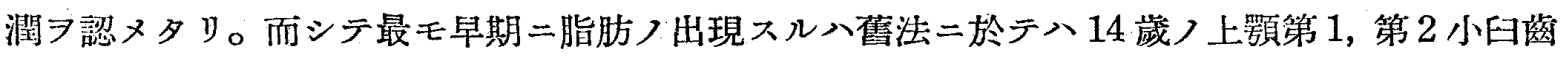

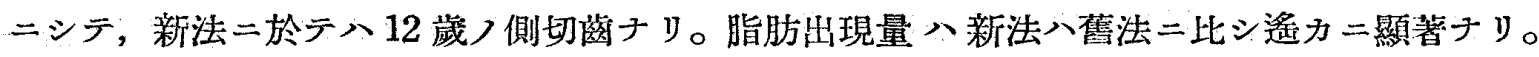
血管壁內被細胞二於テハ舊法ニテ3 例, 新法ニテ 8 例ノ出現フ認メタリ。20歲代ノ29例二於

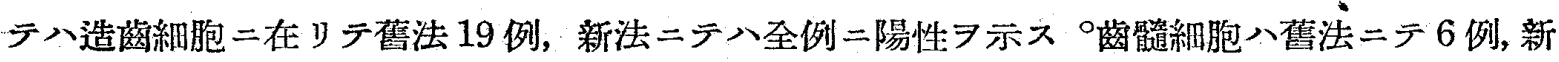

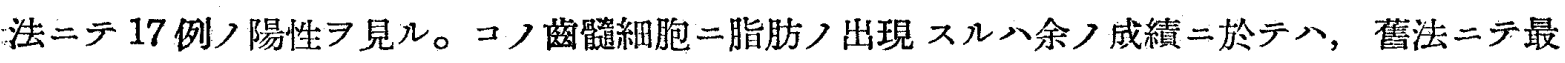

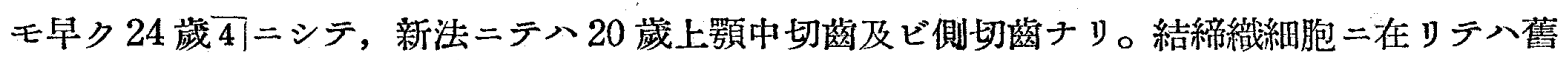

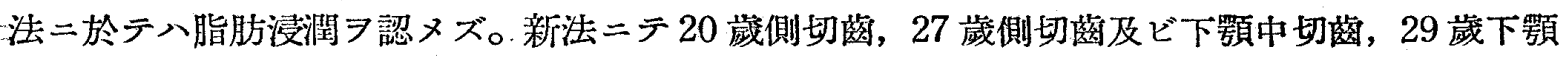
第 3 大臼萄二出現七り。血管內被細胞二於テハ殆ンド全例二脂肪浸潤习認メ, ソノ成績八新法 八䳡法二比シ遙カニ顯著ナリ。コノ年代二於テ上述ノ如ク各細胞二脂肪浸閵ノ出現スル狀海 蓫牙ノ灰化期 7 標準トシテ余ノ分類セル各群ノ苳牙二就キテ觀察スル 二最モ早期二脂肪浸潤 7 見ルモノニシテ，第 2 群及ビ第 3 群二虽スル齔牙二於テ八脂肪ノ出現

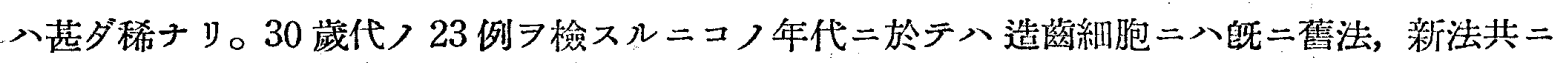
全例二脂肪浸潤 法ニテ 21 例 ニテハ 5 例二出現 見ル。血管內被細胞二於テハ枱ンド全例二新, 舊兩法共二認又得ル所ナ

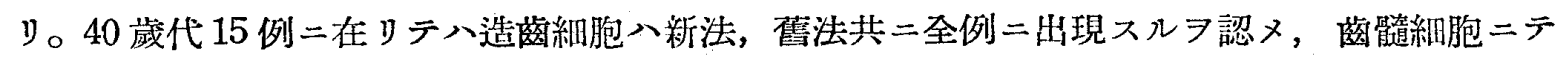
八舊法ニテ 10 例, 新法ニテ 12 例二出現 7 認メ, 一般二年珤命ノ增加卜共二顯著ナル 傾问 ス。結締織細胞二於テハコノ年代二於テモ合木脂肪ノ出現八僅少ニシテ舊法ニテハ認メ得ズ。 新法二在りテ僅カ $=2$ 例二出現ス。血管二在りテハ全例二脂肪浸閵习認ム。 50 葴以上 82 歲二

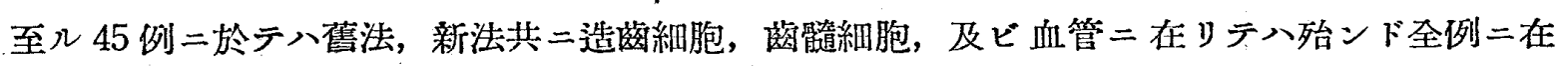

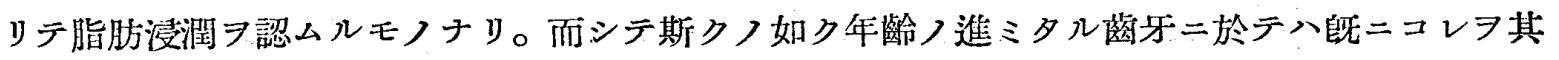
苜牙個々ノ灰化時期ニヨリテ區別スル第 1 群, 第 2 群, 第 3 群二屬スル各齿牙相互間二於テ殆 
ンド同率:脂肪出現シ,ソノ頻度フ區別シ得ザルニ至ルモノナリ。

以上述ベタルガ如ク蓄髓組織二現ハルル脂肪浸潤ノ頻度站二量八, 余つ成績二徵スルモ大體 二於テ年路ノ累加ト共二顯著ナルモノニシテ，コノ事柄八中村氏(11) ノ所見二一致スル所ナ

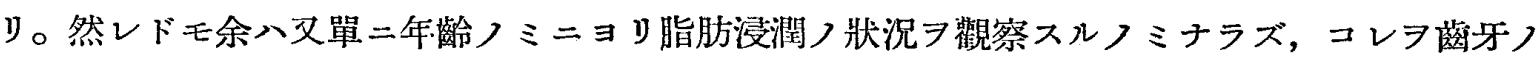

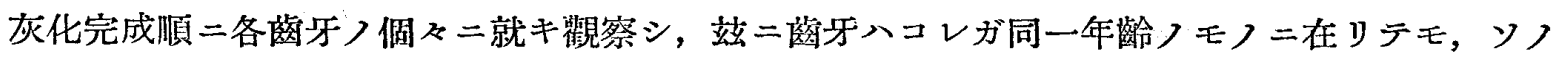

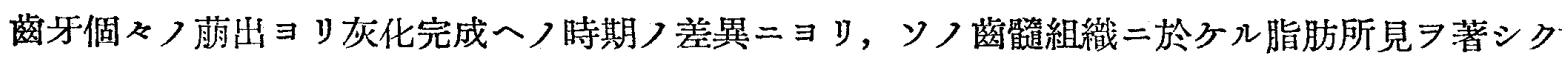

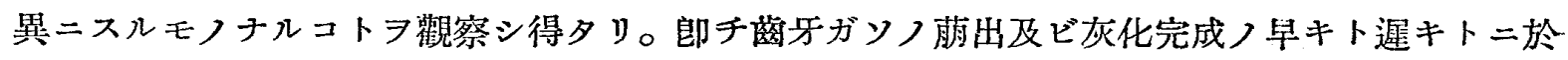

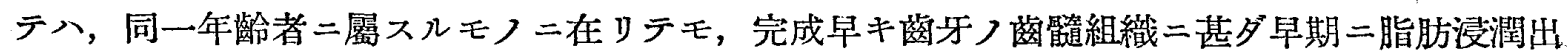
現スル事實习認メ得タリ。依ツテ余八頭初二述ベシ如ク齒牙ノ萠出涉二完成ノ順序二由リ切齿

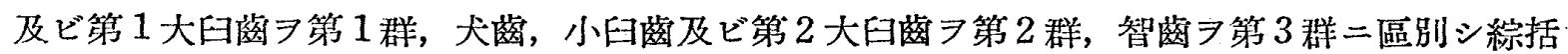

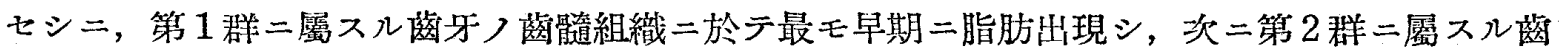

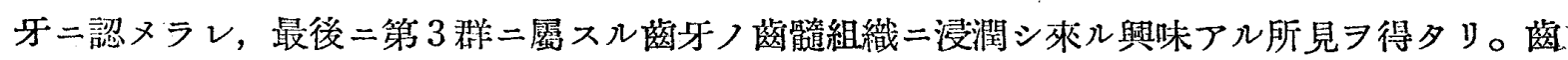
髓組織造茗細胞二於ヶル成績ヨ表示スレバ第 3 表ニ示スガ如シ。

第 3 表 造㱖細胞二於ヶル脂肪出現察ノ比較表

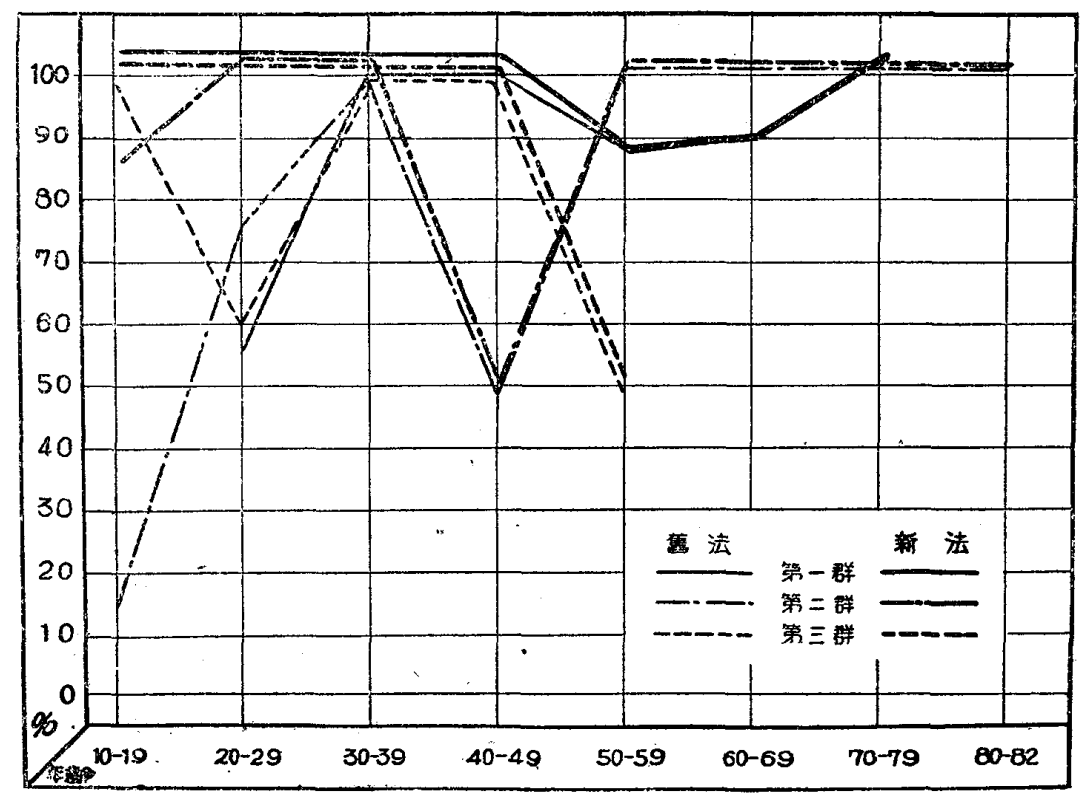

脂肪染色ノ成績八全般的二見テ新法染色法八舊法染色法二比シ遙カニ成績良好ニシテ，余ノ

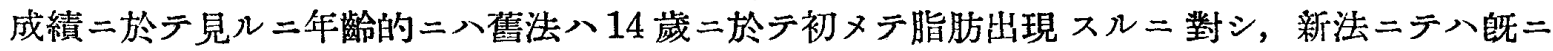
12 筬二於テ出現スルヨ認ム。又新法及ビ舊法ノ染色二由ル脂肪ノ出現量八同一齒牙二就テコレ ヨ比較スル時八新法二依ル場合ガ遙カ二顯著二認メラルルモノナリ。

苜髓組織二於テ最モ早期二脂肪浸潤ノ現ハルルモノ八血管內被細胞ニシテ次デ造挙細胞, 最: 後二齒䯕細胞ノ暊ナリ。 


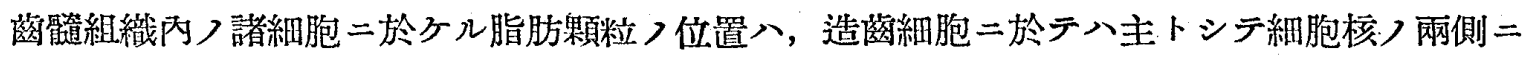
認メラレ，時ニハ外側郎チトームス纎維ヨ出ス側二偏シテ微細顆粒トシテ出現スルコトアリ。

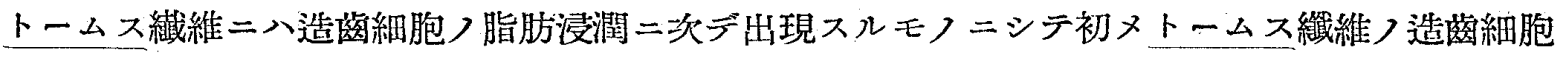
二近半部分二脂肪顆粒ヨ認メ, 浸潤ノ高度トナルニ從ヒ緎維ノ全長二互り出現スルニ至ルモノ ニシテ,コレ等ノ成績ニ關シテハ既二象牙質ノ所見ノ部ニ於テモ述ベシ所ニシテ,象牙質蒰細管

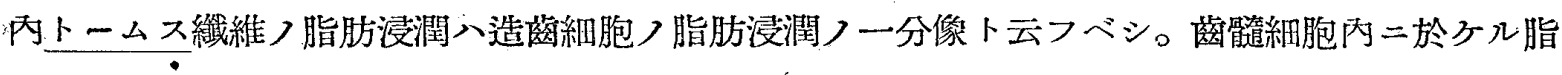
肪顆粒つ位置八原形質ニコレタ認ム。血管ニ於テハ血管壁內被細胞內二出現ヨ見ルモノナリ。

脂肪顆粒つ形態八舊法染色ニヨルモノ八概亦微細ナル滴狀，顆粒狀或ハ棉狀ニシテ時ニ牛月 狀丈八指輸狀 $习$ 呈シ，大サ八大小不同习呈ス。新法染色二ヨル時八概亦滴狀 ナル例二於テ八常二美曧ナル大滴狀トジテ認メ得ルモノナリ。

脂肪ノ色調八舊法二由レバ污褐赤色, 黃赤褐色, 又八淡赤色 美麗ナル橙赤色ヨ呈ス。脂肪ノ性狀八川村氏(6) (7))群簇反應 ド」ニ屬スルモノナリ。

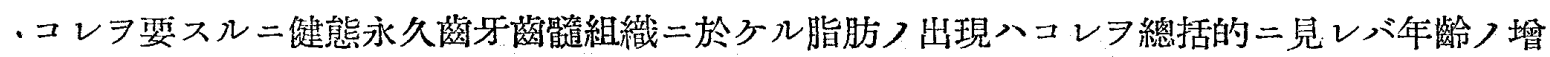

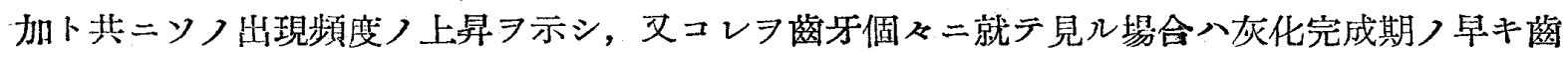
牙入喊髓組織二於テ最モ早期二脂肪浸潤つ起ルラ知ル。

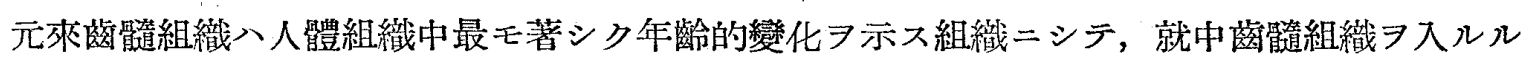
蒛䯕腔ガ年齡的二變化ヨ招來スル事實八特ニ注目スベキ事ニシテ, Fischer 及ビ Hess ノ研究

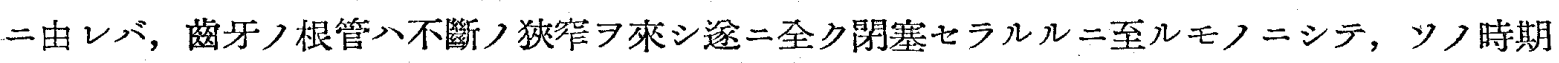

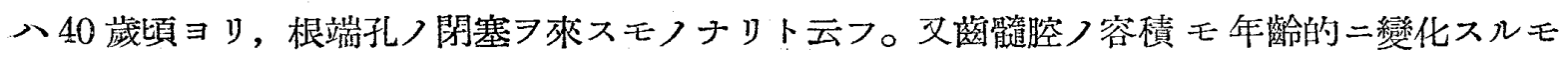
ノニシテ, 非常二緮慢ナル蓠髓表面二於ヶル象牙質, 構成二由リ全生涯ヨ通ジテ持續的二狹窄 ガ行ハルルモノニシテ，コレ等ノ所見二關シテハ J. Șzabo(14)，K. Trueb,(47)，中村氏(12)等)

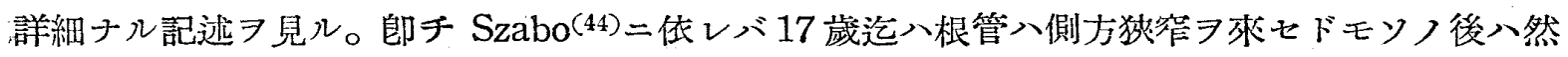

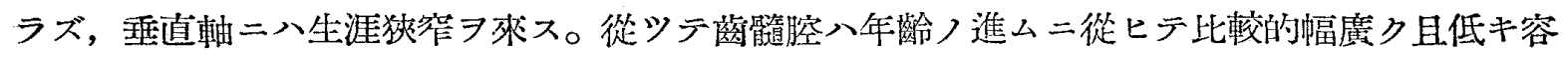

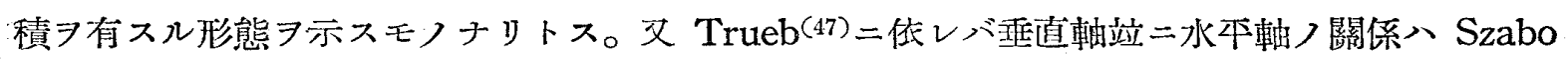
ノ述プル所二一致スルモ，ソノ水平軸二於アル塽窟モ亦高年迄繼續七ラルルモノトナセリ。中

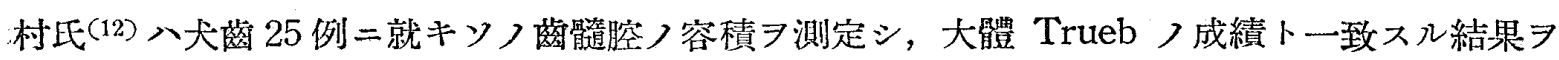
得タリト報告七リ。以上述ベタルガ如ク, 何レニシテモ齒髓腔ノ容積入年龄つ增加卜共二狹窄

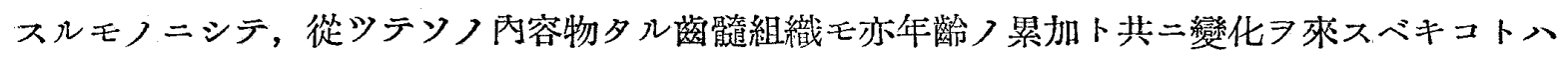

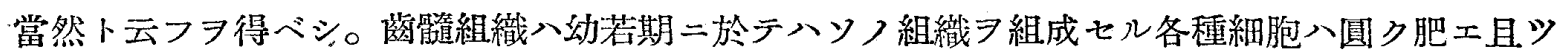

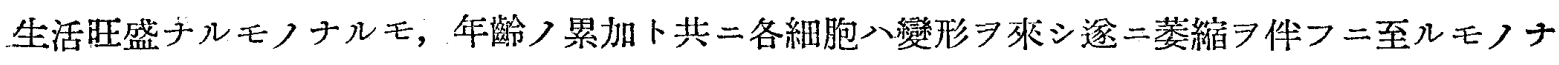

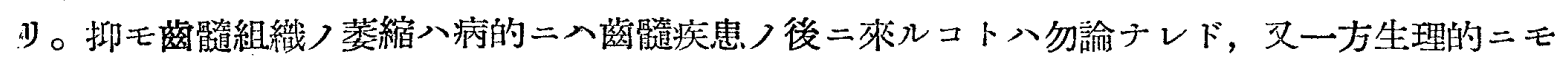


年齡的變化トシテ來ルモノナリ。

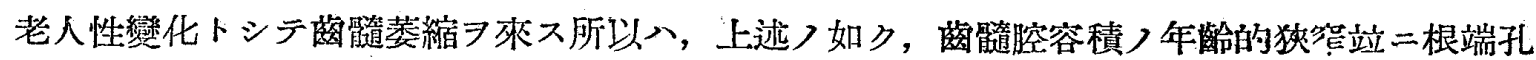

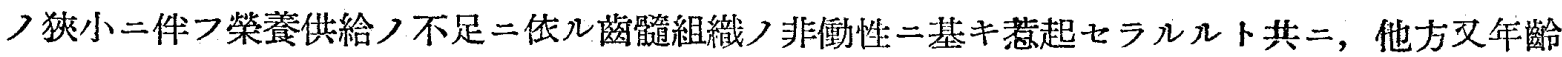

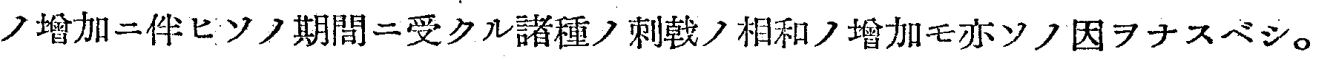

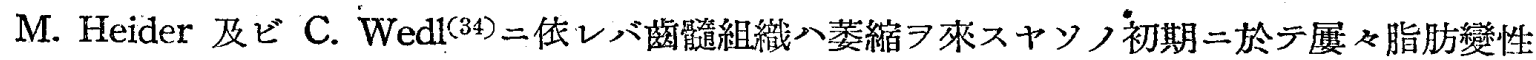

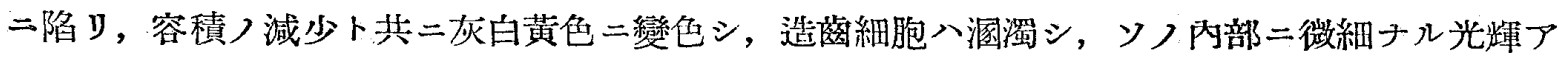

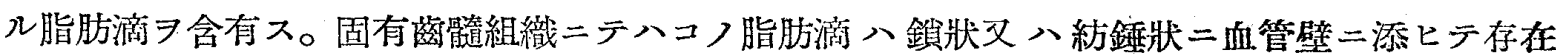
シ，神經緎維八自身脂肪變性二陷入ルニ至ル。

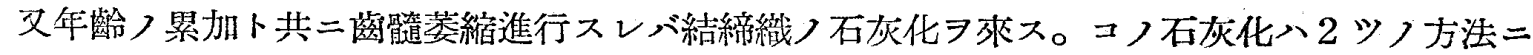
依リ行ハル。師チ細胞自身石灰化スルカ或八細胞二關係ナク游離シテ間質中二石灰粒ヨ沈著

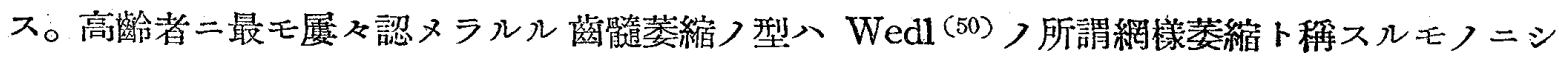

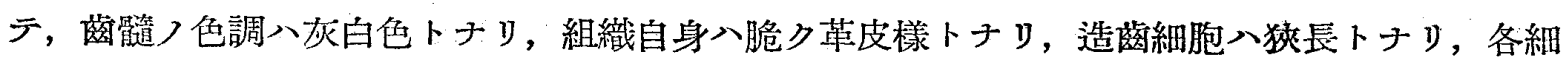
胞間二空胞狀間隙フ形成シ，時二空胞間二存在セル造蒛細胞八壓扁萎縮七ラレ，核ハ相集合シ

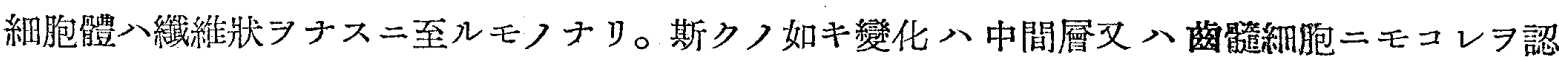

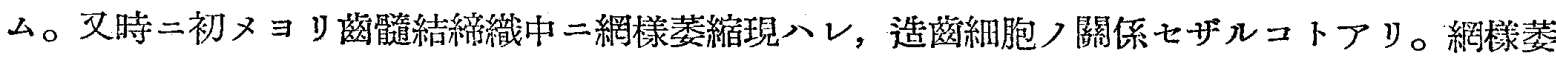

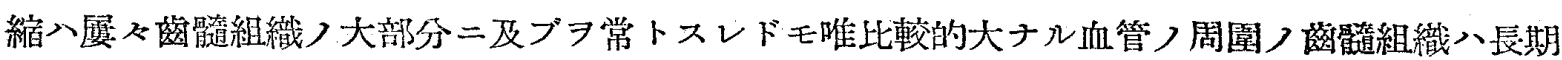
間ソノ變化二抵抗スルモノナリ。然リト踓モ斯カル部分モ結局八萎縮二陷ルモノナリ。以上述

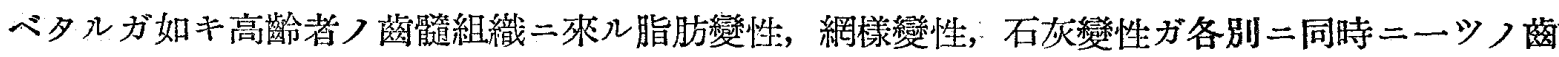

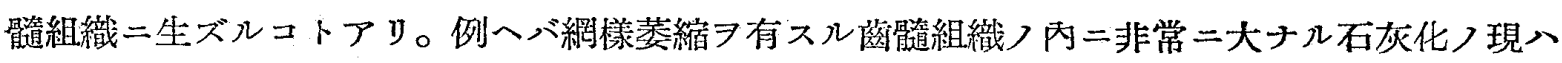
ルルガ如シ。サレドソノ成立機轉ノ順序八通常先ジ脂肪變性次デ網樣萎縮二及ビ逐二石灰沈著 ヨ招クニ至ルモノナリ。

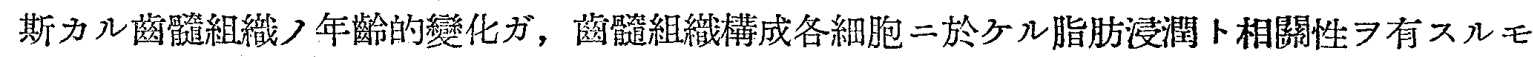
ノナルコトハ毁二詳述セル所ニシテ，大體二於テ落䯕組織二退行變性ノ生ズルト共二脂肪漫潤

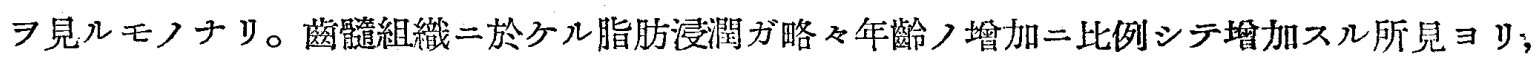

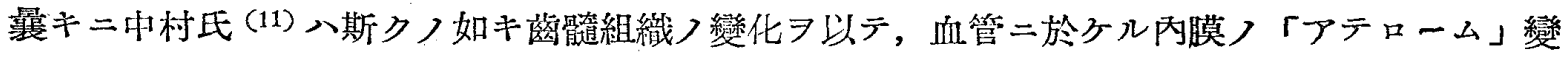
性, 眼球角膜二於ヶル老人環, 老人性難聽二於ふル鼓膜つ戀化卜同樣二一種ノ老人性變化ナリ

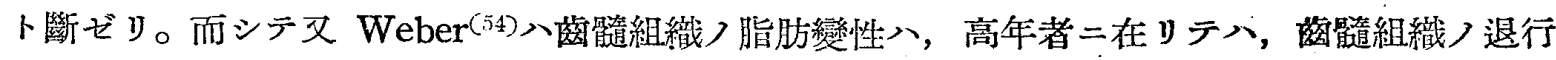

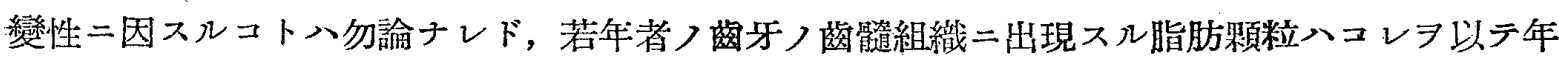

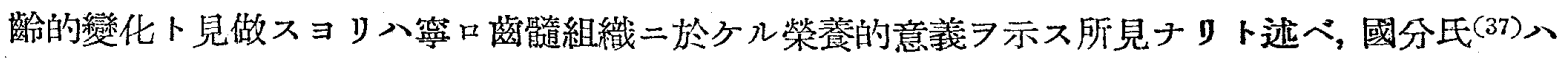

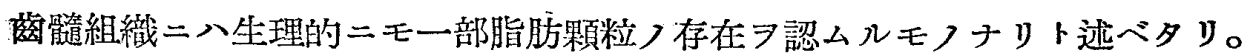

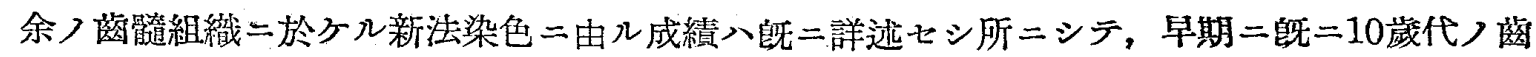

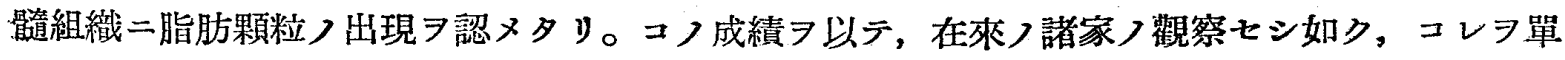




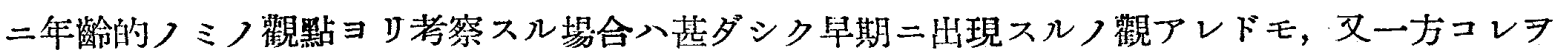

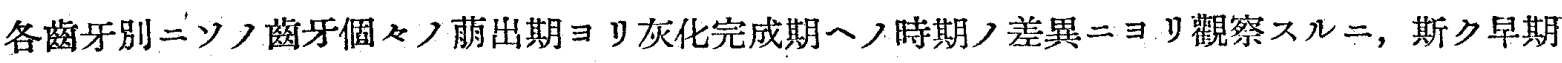

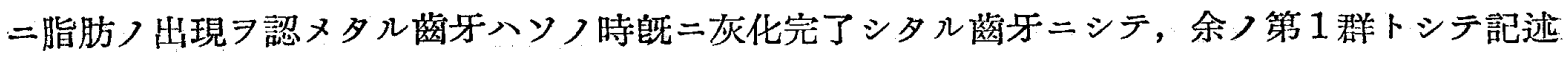

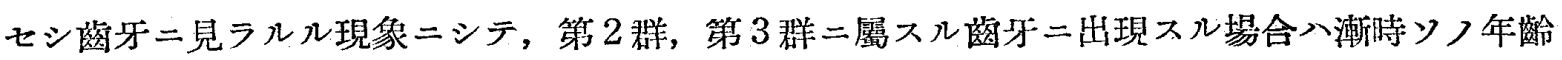

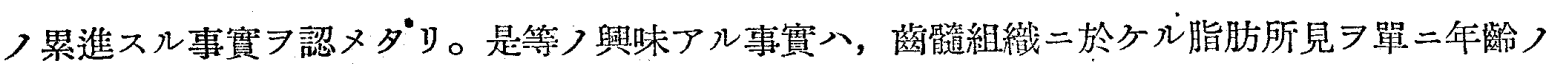
ミヨ以テシ，コレヨ退行變性二因ル現象ナリト斷ズル事ノ不合理つ如ク感ゼラルルモ，罂牙個

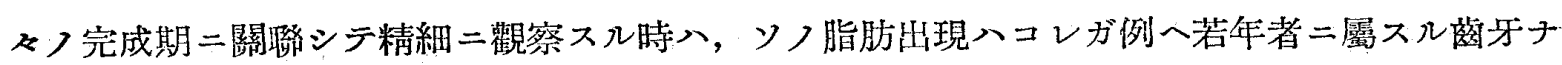

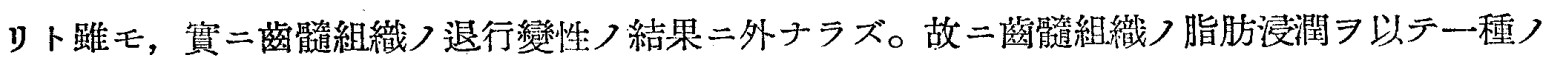
年跉的變化卜見做ス八余モ亦ソノ研究成績ヨリ最モ穻賞ナル所見ナリト思惟スルモノナリ。而 シテヌ脂肪顆粒つ早期出現ハヌーツニ染色法つ進步發達二モ起因スベク，新法染色法八薈法染 色法 以テ尚ホョク證明シ能ハザリシ脂肪質つ存在 $モ$ 明膫二簡明シ得ル最モ優秀ナル脂肪染

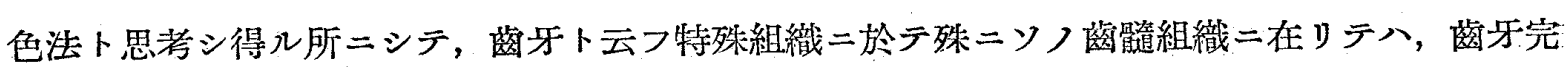
成後八早期二退行變性ヨ示セルモノナル事习知リ得タリ。

第 5 . 編 喵、根膜脂肪所見

䕎根膜組織二於テハ造白型細胞, 結締織細胞, 及ビ血管二就キソノ脂肪浸潤ノ狀況习觀察七 リ。ソノ所見 7 年路別二述ブレバ造白朢細胞ニ於デハ䳡法ニテ 44 歲 $\mid \underline{2}=$ 最モ早ク脂肪顆粒

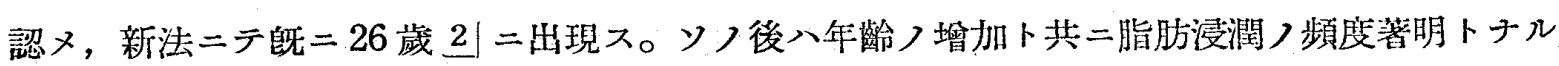

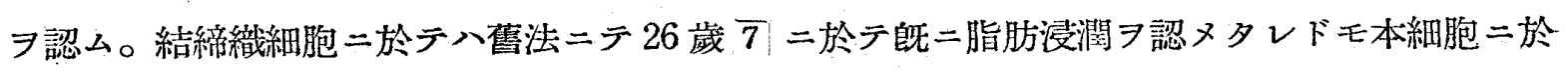
テハ脂肪ノ出現率八新舊兩法共二概シテ甚ダ僅少ナルョ見ル。血管壁內被細胞二於テハ舊法二

第 4 表 造白惡細胞二於ヶル脂肪出現率比較表

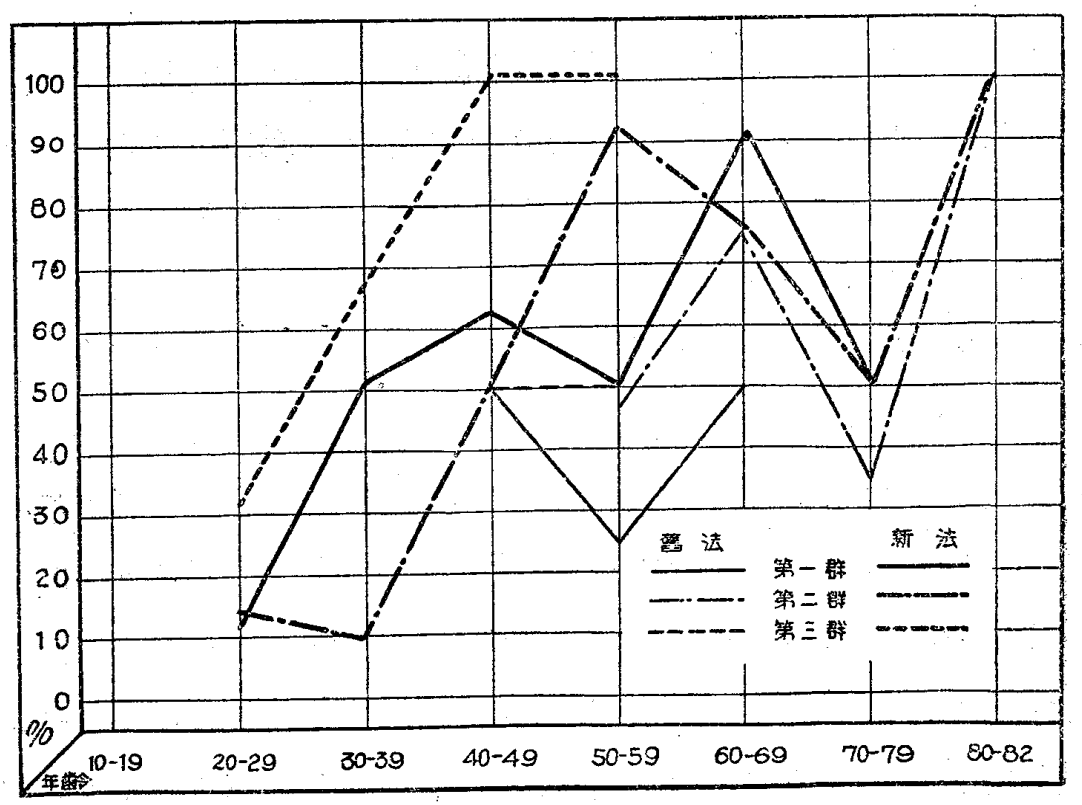




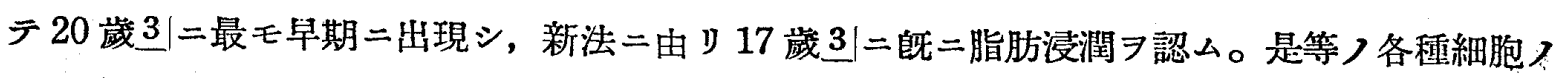
內造白型細胞又成績习表示ネレバ第 4 表二示スガ如シ。

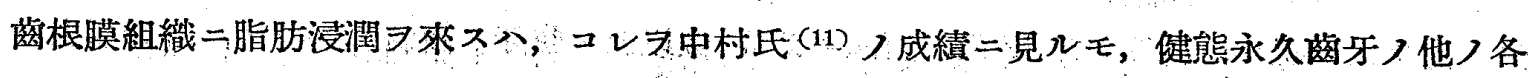
組織ヨリ著シク掘レテ出現シ，造白㤠細胞二於テ 32 歲 $\mid \underline{2}=$ 最モ早ク，結締織細胞，血管壁内

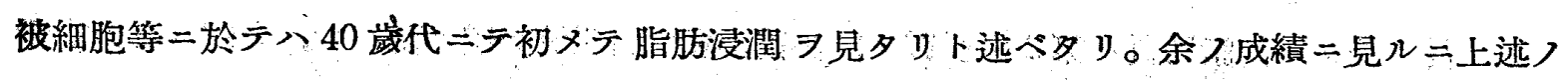

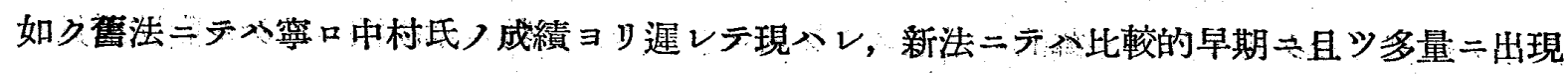
スルト踓モ，他つ組織ニ比ネレバソノ出現入著シク逯レルモノさり。脂肪フ出現頻度入結締織

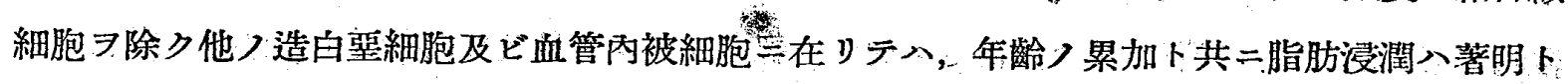
ナリ，50歲以上二於テ八常二認メラルル所ニシテ,コク所見八他つ組織ト同一傾间 ヨ示スモノ. ナ哭

脂肪つ形態學的所見入舊法, 新法共二主トシテ大小不同ナル滴狀ヨ呈スルカ, 叉微細ナル 顆粒狀 $\ni$ 呈え。色調入舊法二テ赤褐色, 黃赤褐色乃至活赤褐色 $コ$ 呈スル二反シ, 新法ニテ八常 二美麗ナル橙赤色ヨ是スれもナリ。是等脂肪つ性狀入川村氏群屬反應ヨリ「リポイト」二屬 スベキモノナy。

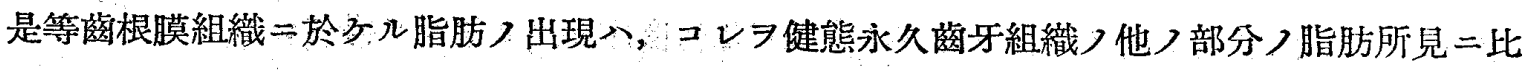

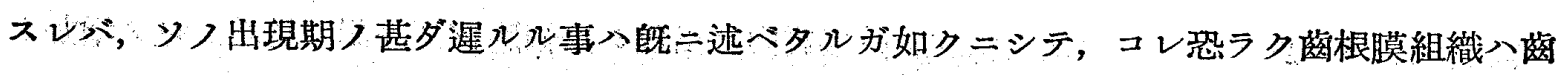
牙組織中二於テ最モ著シク周圍組織卜ノ關低密接ニシテ, ソノ生活力モ亦旺盛二且兴榮養供給 良好ナル二因スベシ。然り卜踓モ20歲代ヨリ脂肪ノ出現 7 認メ，40歲以上ニテ出現顯著卜す

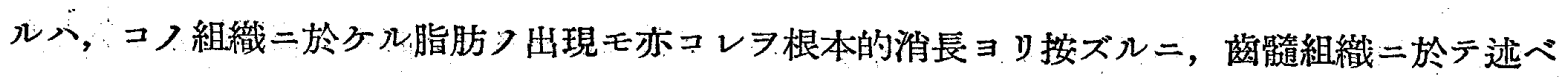
タルガ如ク，一種つ老人性變化卜見做スベキ所見二一致スルモノナリ。

\section{第 4 童 全編 ，總括立立二考按}

健態永久䓨牙各組織二於ヶル脂肪出現ノ狀態入, コレア余ガ舊法及ビ新法ノ染色法ニョリ系

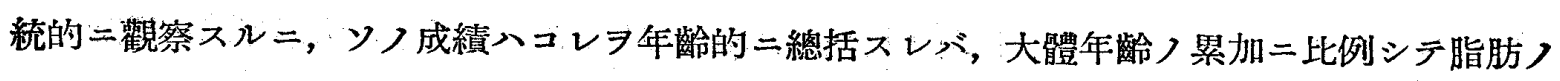

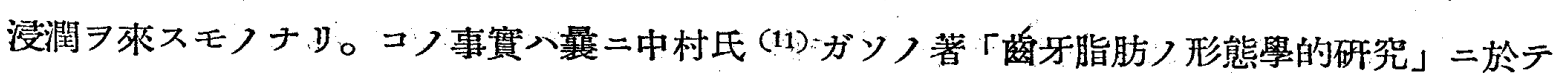
述プル所ニ一致スルモノナリ。

新法二依ル脂肪染色ハソフ成績甚ダ優秀ナルハ, 各組織二於アル所見二於テ既二詳迅セシ所 ナレドモ健態永久苳牙二於テハコノ新法ヨ以テシテモ年龄的二八佾ホ 12 歲未滿つ若年者つ苳 牙二於テ, 形態學的二全》脂肪質习認メ得ズ。舊法ニテハ 14 瓷ニ於テ初メテ脂肪質 7 認ム。 兩法共ニソノ後年龄つ䒺加卜共二漸次脂肪出現ノ頻度及ビ量 7 增進スル 認ム。今余ノ健態永 久菌牙各組織ニ於ヶル脂肪所見习要約スレバ次り如シ。”

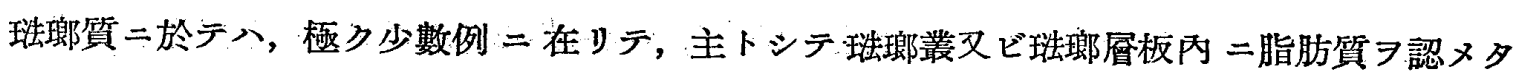


Y.

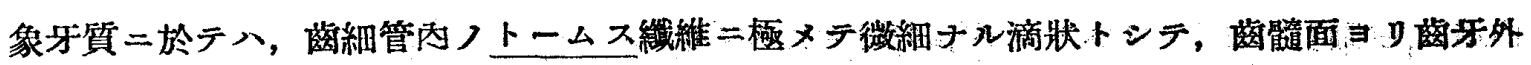

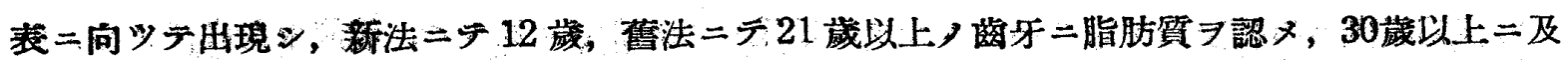

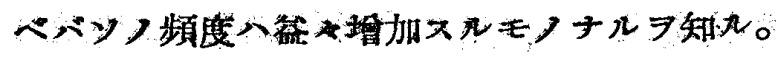

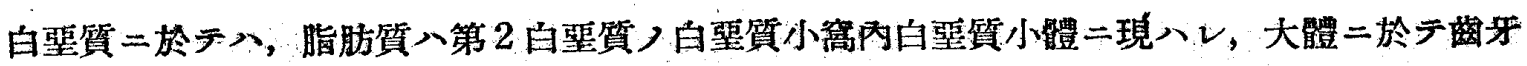

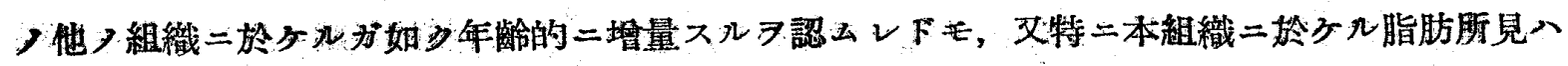

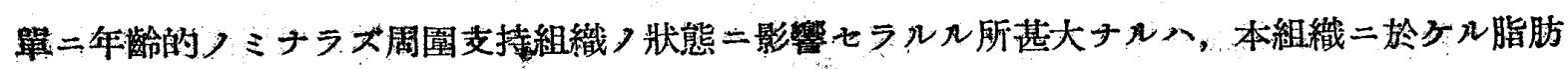

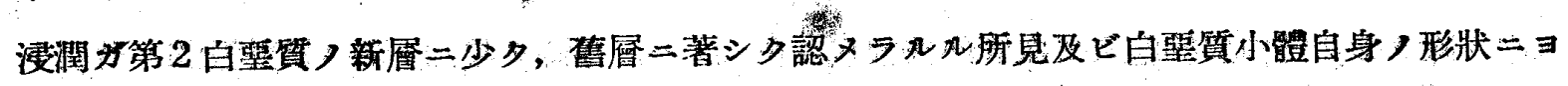

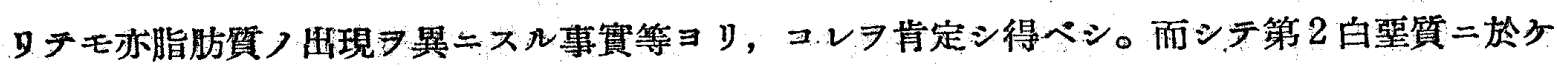
几脂肪浸潤八, 新層郎チ表屏二少ク, 舊層郎チ深層二著シク, 又同一層內二於テモソノ內二含

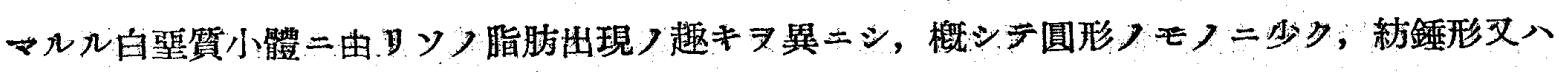

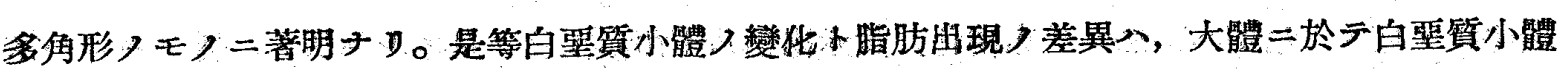
自身つ退行つ表徵卜一致ス卜認メ得ベク，斯力九白壁質小體自身つ脂肪所見

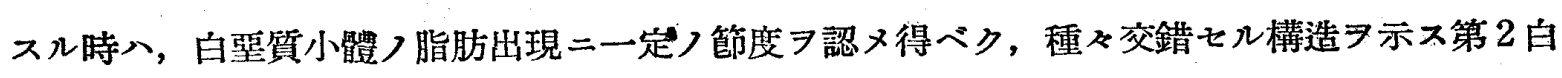
壁質モ，ソ〉脂肪所見ヨリコレガ形成過程及ビ生活機序习賽ヒ知ルヨ得ベシ。

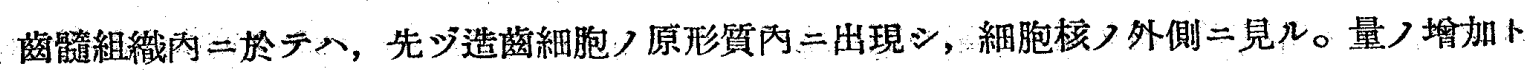

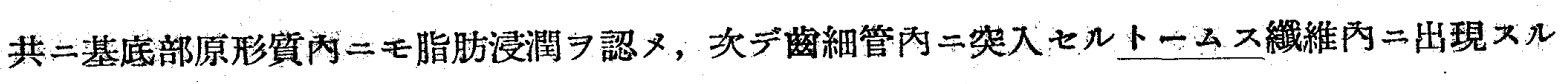

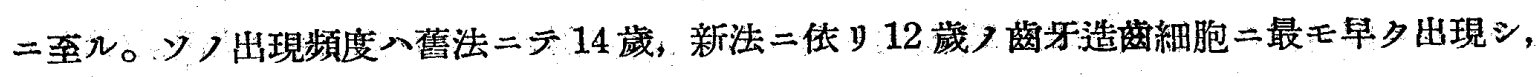

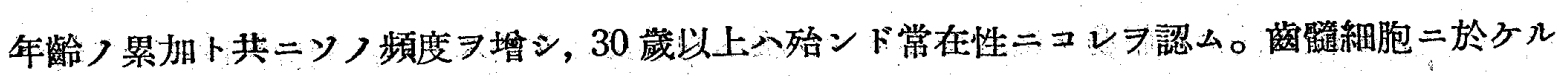

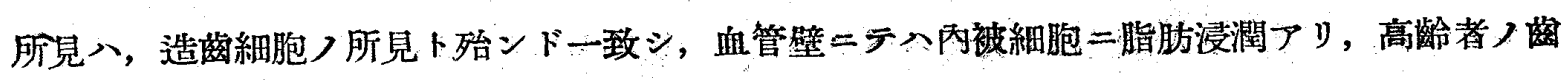
䯠つ血管ニテハ更ニソノ外膜瀻維ニモ脂肪浸潤习來ス。

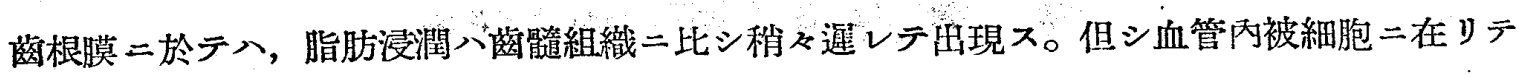

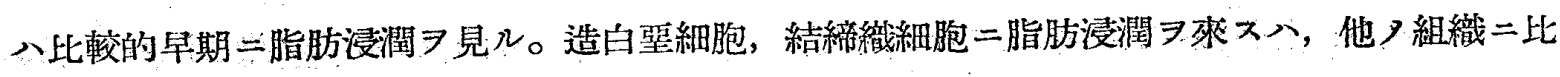

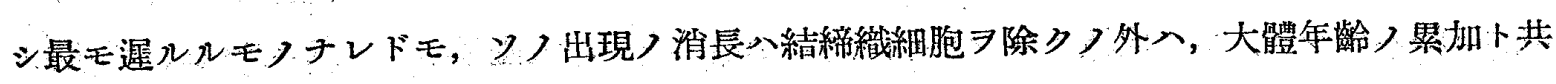

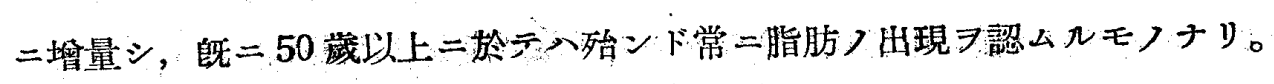

苳牙ノ各組織二浸潤スル脂肪ノ形態 7 見ル二,舊法ニテハ主トシテ滴狀 指輸狀入八桿狀习呈ス。大サ八概シテ微細ナレドモ及時二浸潤著明ナれモノ二於テ大ナル滴狀 ヨ呈スルモノアリ。新法二於テ見ル形態入主トシテ美麗ナル滴狀タナシ，圆形习呈スルモノ大 部分ナルモ，時二不正圆形又入斑點狀ヨナスコトアリ。大サ八微細ナル塵埃狀ヨ・大滴狀二至 ル種くナル大サヨ示ス。

脂肪ノ色素二對スル反應八, 鹤法ニテハ光輝ナキ赤褐色叉メ黄褐色ニシテ, 新法ニテハ美麗

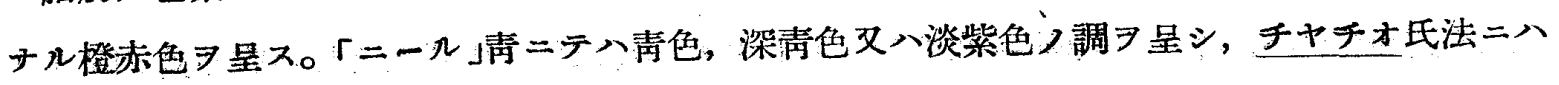


楊性ナリ。

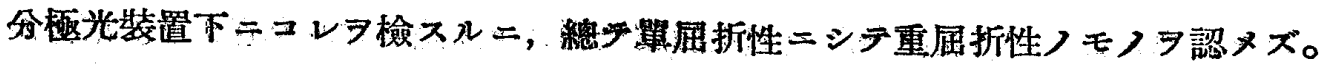

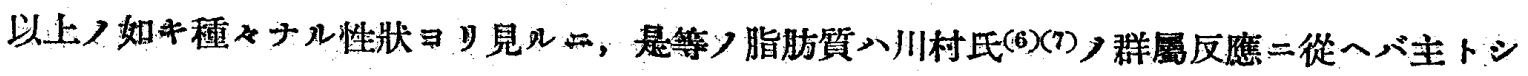

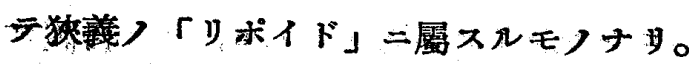

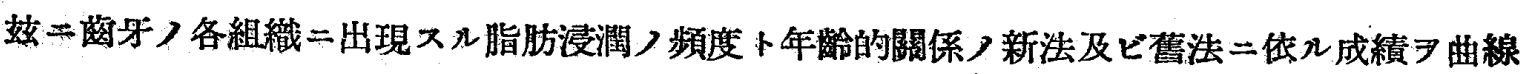

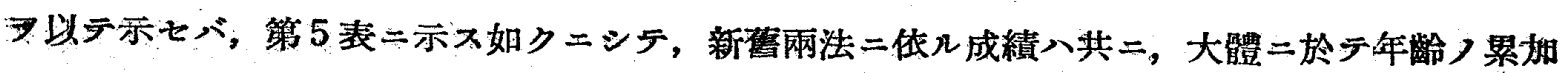
トー致シテ脂肪出現ノ增量セルコトワー見シデ首肯シ得ベシ。

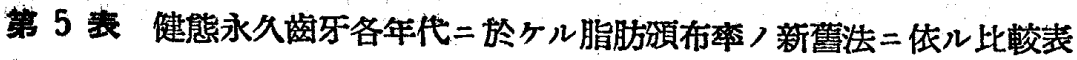

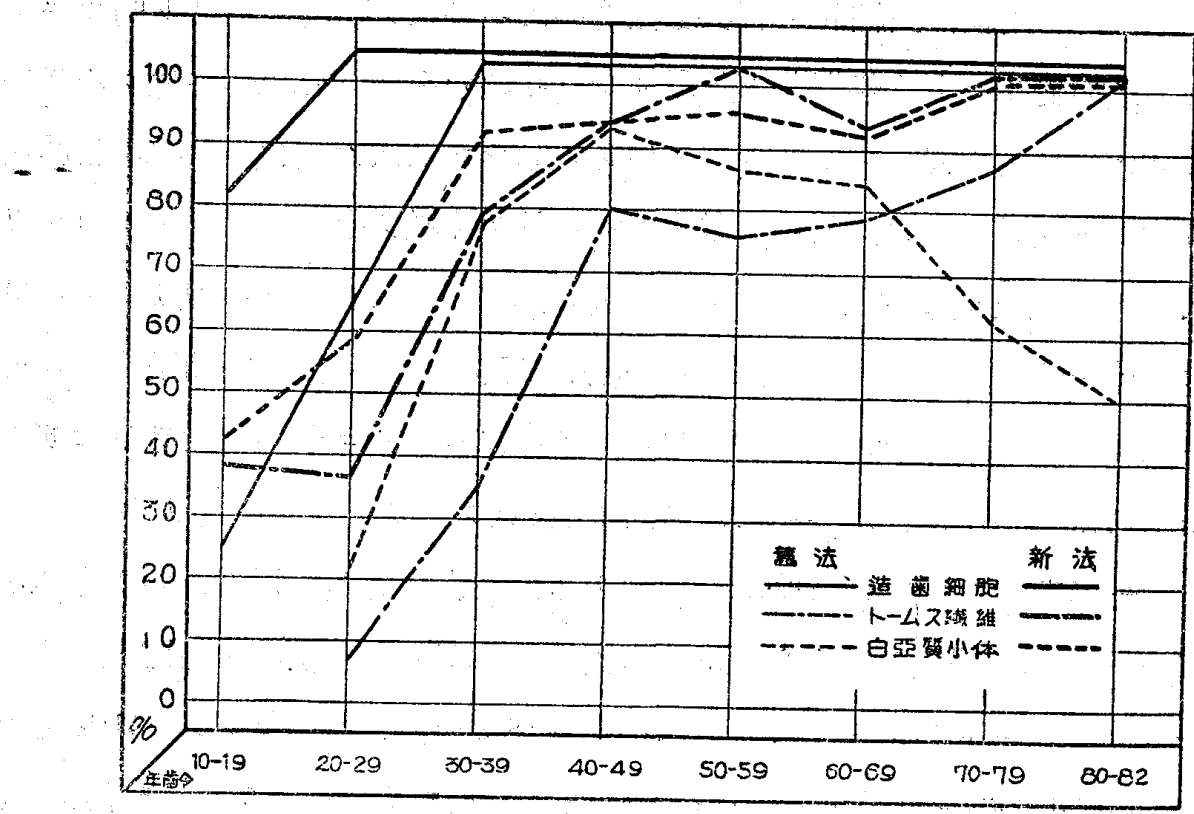

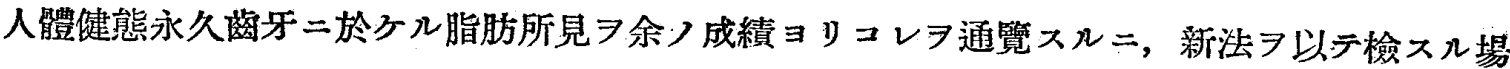
合八舊法ヨ以テ檢スル場合二比較シ遙カ二早期二且ツ著明二出現スルモノナリ。

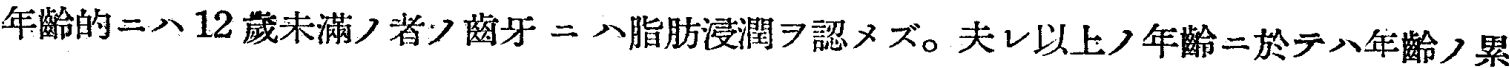
加小共二脂肪出現つ頻度

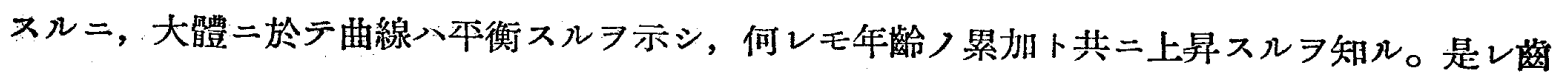

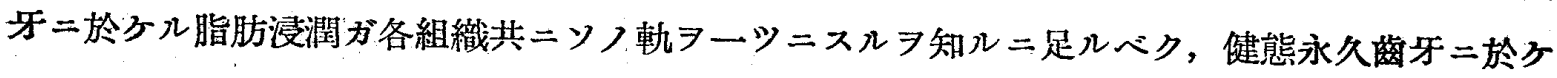

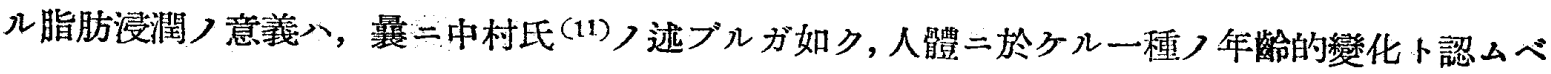

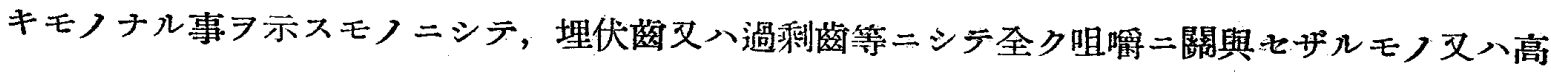

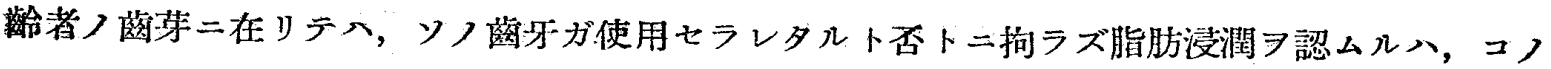
間ノ事䁈

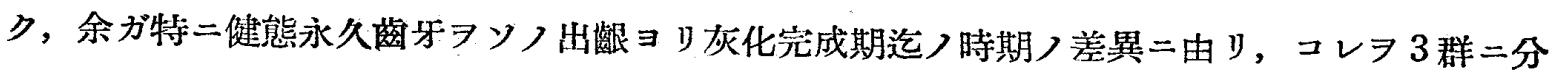

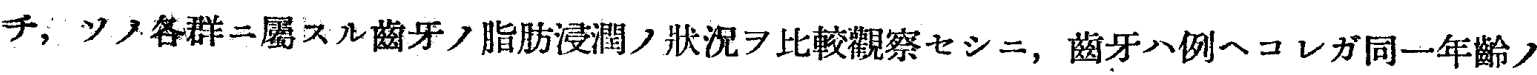




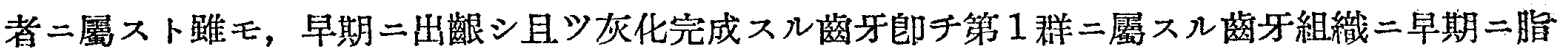

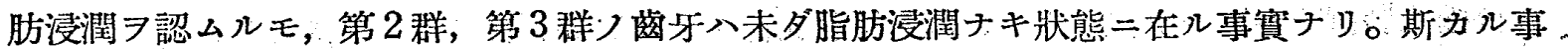

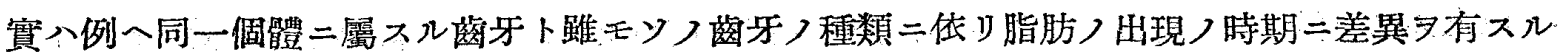

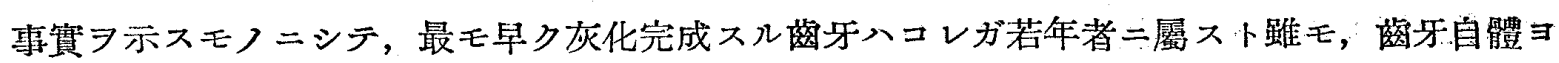

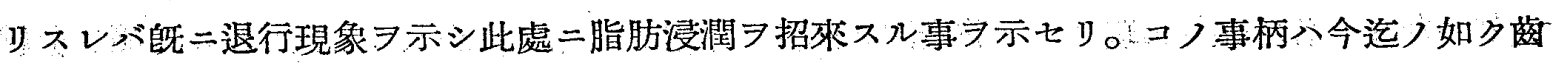

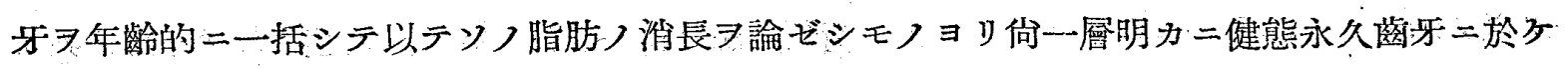
ル脂肪浸潤ガ退行變性二由來スルモノナル事习證スルニ足ルモノナリト云フラ得ベシ。

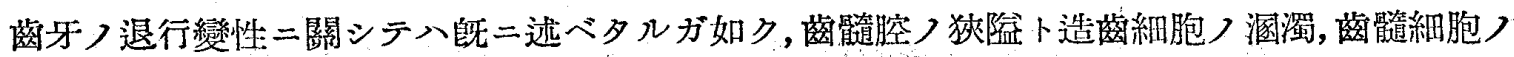
脂肪變性, Wed1 (50)八所謂網樣萎縮岦二石灰變性等八巳二多數ノ研觉者二ヨリ明カニセラレタ ル所ニシテ，是等つ諸變化八老人性變化卜見做サレ，健態永久翠牙各組織二於アル脂肪浸潤モ 亦一種ノ老人性變化卜見做シ得ルコト入悓述ノ如シ。而シテ老人性變化二於ヶル脂肪浸潤ノ意 義八常二重要視サルル問題ニシテ, 既二人體諸臟器二於テ多數つ學者つ報告スル所ナリ。就中 老性變化)著明ナル一現象タル動脈硬化症二モ Virchow (48), Marchand (38), Ribbert (43), Jo-

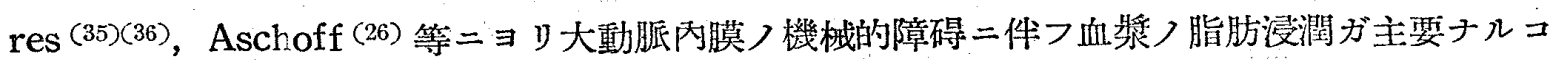
ト明カトナルニ至レリ。向ホ Jores ${ }^{(35)(36)}(1903-4)$ 八未ダ明カニ硬性變化 在リテモ,動脈壁つ深層殊二彈力筋首二斯カ儿變化 Arteriosklerose $ニ$ 代フルニAtherosklerose ナル名稱习提唱セリ。以上ノ如ク動脈硬化症八 ソノ內膜內脂肪浸潤二依リ招來七ラルルコトラ事實トスレドモ，血漿中ノ脂肪量习人工的二增 加セシメテ茲二「ヒペルコレステリネミー」Xハ「リペミー」フ䓯起セシメタル埸合八, コノ Atherosklerose $习$ 意起シ得ルヤ否ヤノ問題八, 動物實驗ニヨリ明快ナル解決ヨ得タリ。Star一

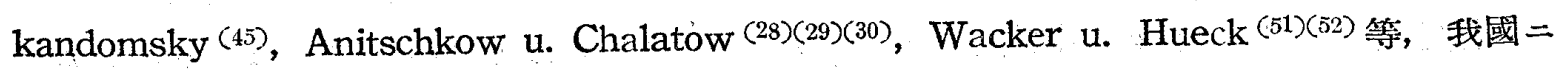
於テ今 (8) (9), 角田 (22)(23), 川村 (7), 中院氏 (13) 等)多數二ヨリ試ミラレタル家兔ノ「ヒョレ

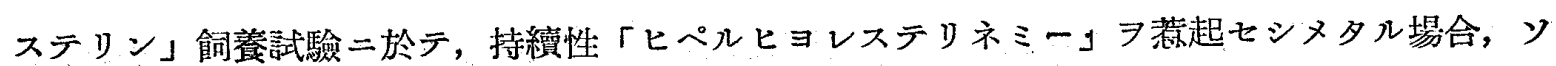
ノ動脈就中大動脈二脂肪殊二「ヒヨレステリンェステル」ガ主トシテ內膜二沈着シ，人類二見 ルガ如ク Atheromatose 變化ア巷起セシメタリ。メコレニ加フルニAnitschkow 八家杏二化 學的泣二機械的障碍 コトフ得タリ。然レドモ家兔二於テ，普通ノ「ヒョレステリン」飼養ニョリコレヨ見ルコトヨ 得ザルハ, ソノ生存期間ノ短小ナルニ由ルぶシト (Aschoff(27))。

中院氏 (13) 八又家鬼ノ角膜ニ「ヒヨレステリンエステル」ノ沈著习薏起シ，恰モ老人性變化 卜見做シ得儿人類ノ老人環卜同一性變化习生ゼシムルコトラ得タリ。コノ事實入後二於テ獨逸

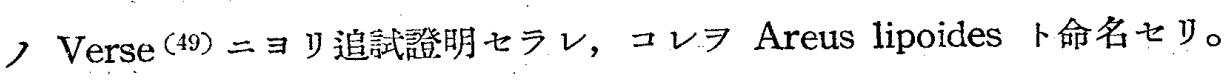
結締組織ノ老人性變化トシテ,ソノ脂肪變性ノ留意スベキコト前述ノ如キ大動脈ノ外二, 


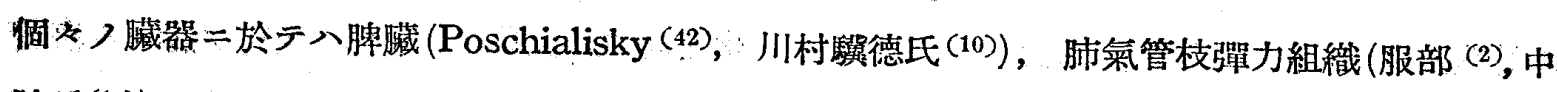

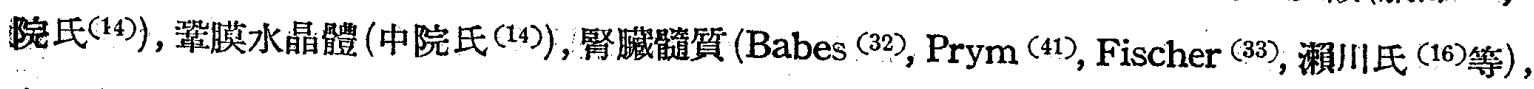
角膜 (川村氏 (7)), 鼓膜 (中院氏 (14)), 硬腦膜, 筋腱等) 硬固結締織 (今氏 (8)), 軟骨 (田中 (24), 山極及ビ山本 (25)，服部氏 (2)) , 等ノ多數つ報告フ見ル。是等 7 間質性脂肪變性トナシ，廣汎ナ ル材料二基キ綜合的二觀察シ，ソノ變性つ部值，脂肪つ性質，出現つ要約，其他つ變性卜ノ關

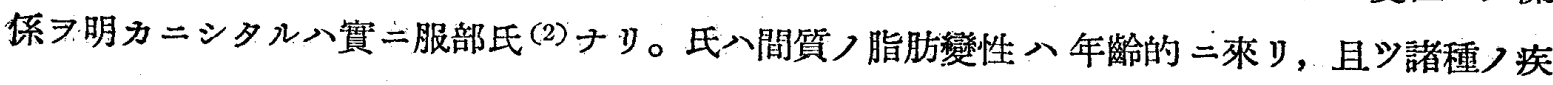
病的障碍ノ爲メニ組織ノ消耗习來セルモノニシテ, ソノ脂肪沈著八組織退行變化ノ一ナり卜結

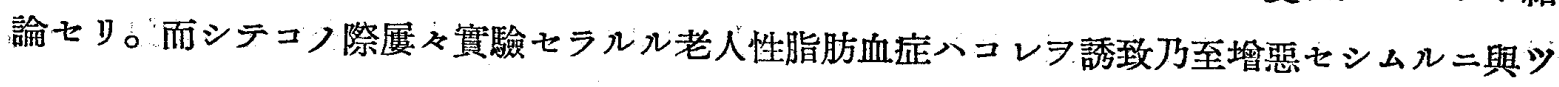
テカアルベシ (Wacker u. Hueck (51)(52)，中院氏 (14) 等)。

次二老性變化二對スル脂肪ノ意義二關シテハ 2 樣ノ見解アリ。師チソノ1ツハ組織二於ヶル 脂肪浸潤》以テ一次的郎千原因的意義有スルモノナリトナスモノニシテ，ソノ2 ハコレタ以 テ二次的郎チ組織ノ生理的衰调二依ル策養障碍ノ結果脂肪浸潤习來スニ至ルモノナリトナスモ $ノ+y_{0}$

今健態永久苜牙各組織二於ヶル脂肪浸閵つ意義 7 按ズル二, 余ノ成績二徵スレバ既述ノ如ク

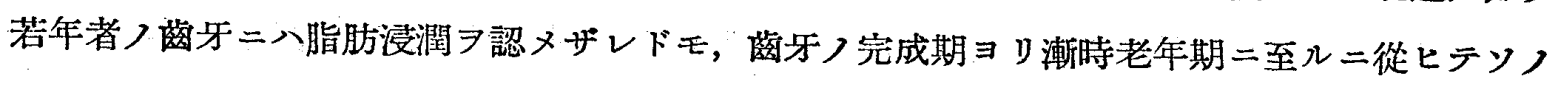
年龄つ累加卜共二脂肪出現ノ頻度及ビ量つ增加习認ムルモつナリ。斯クノ如ク一般二若年者つ 灰化未完成苳牙二脂肪出現七ザル卜踓モ, ソノ者ノ有スル灰化完成䔄牙二八少量ノ脂肪浸潤

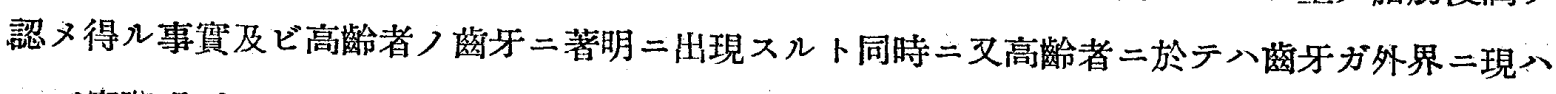

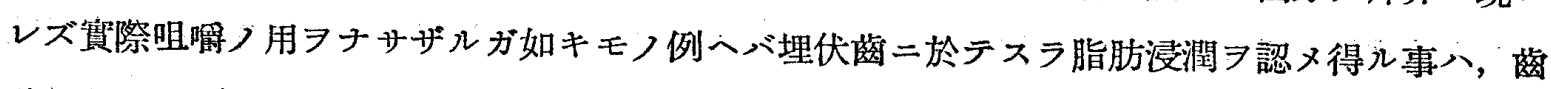

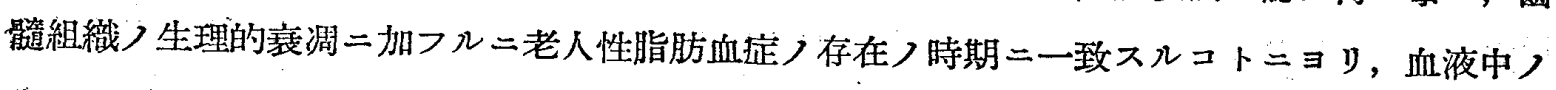

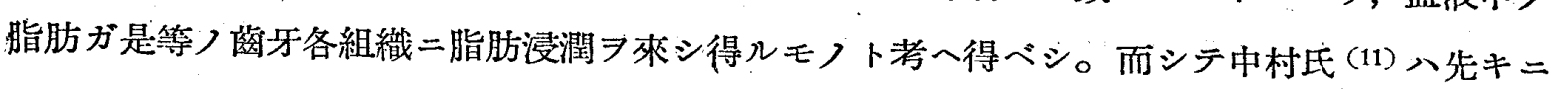

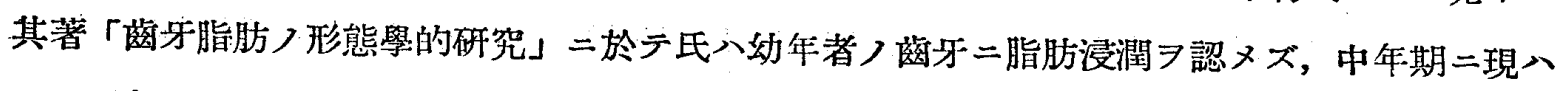
レ, 老年期 $=$ 至ル二從ヒ常在性トナルハ人體つ他ノ一般間質組織ノ脂肪變性卜同一視スベキモ うニシテ, 是レ實二一種ノ老人性變化ニ外ナラズトナシ, ソノ脂肪浸潤八老人性脂肪血症及ビ 組織つ退行變性二起因シテ出現スルモノニシテ, 諸種つ老人性變化つ內最モ早期二出現スルモ

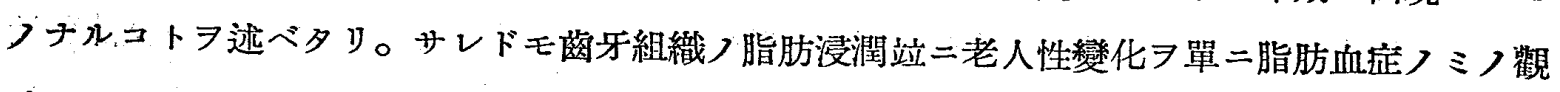
點ヨリ說明スルコトハ稍々困難ナル事アリ，例へバ人體健態乳萄ガソノ交換期二至ルヤ向ホ正 常二近キ形態

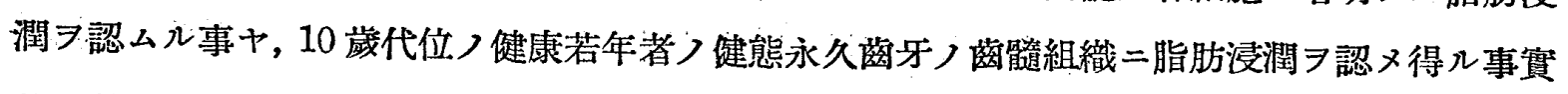
等, 是等 7 悉ク脂肪血症二由來ス儿結果ト解スル 得ズ。吻論例外的二八若年者卜踓モ諸種

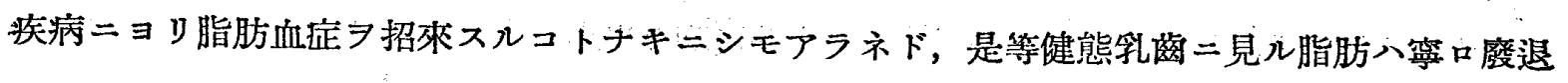

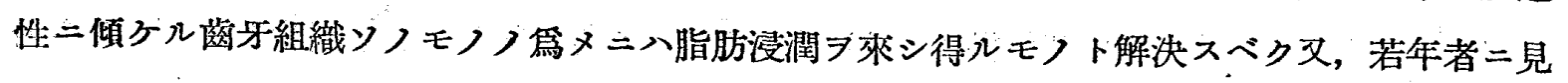




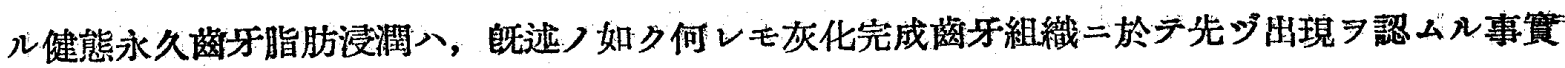
ヨリ, 斯カル現象モ亦早期二現ハレタル䍃牙織ノ生理的退行變性二由來セシモノニシテ

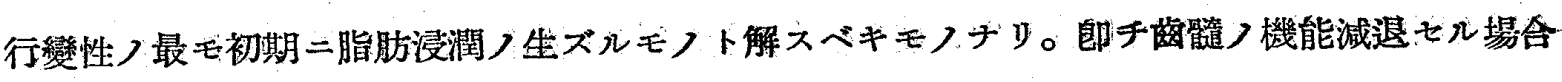
ニ八，一般脂肪血症〉有無二關係ナク老性變化ト同㥞ナ儿變化 牙二於テ一般二認メラルル老性變化郎チ網樣變性及ビ石灰變性卜脂肪變性卜入如何ナル關係二

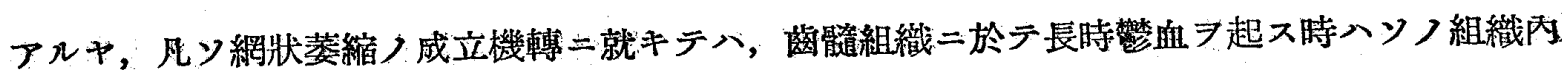

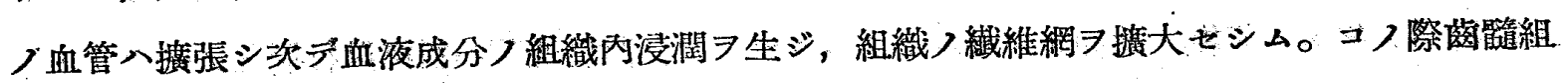

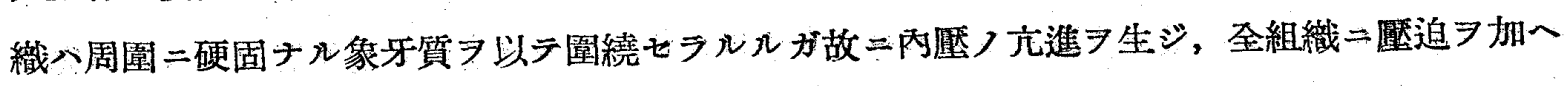

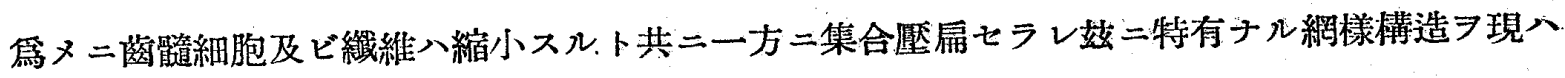
スニ至ルモノテルベシ。而シテ斯クノ如クニシテ生ジタル網眼內二含マルルモノメ，水樣透明

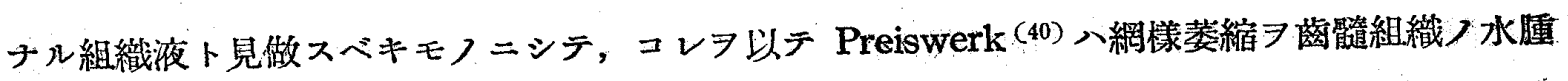

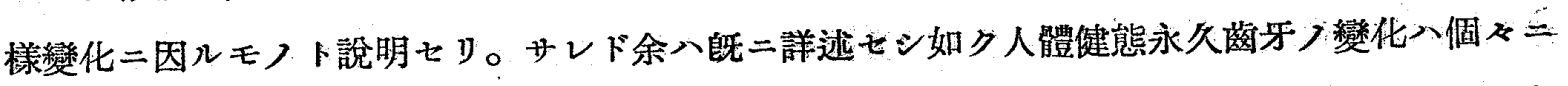
ヨリソノ變化發現ノ時期习異ニスルモノニシテ, 同一個體ニ於テモソノ缹牙

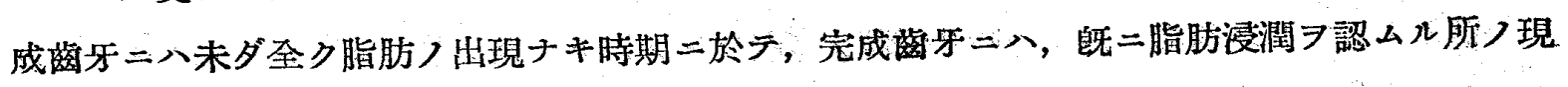

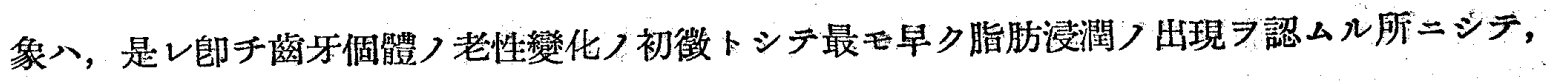

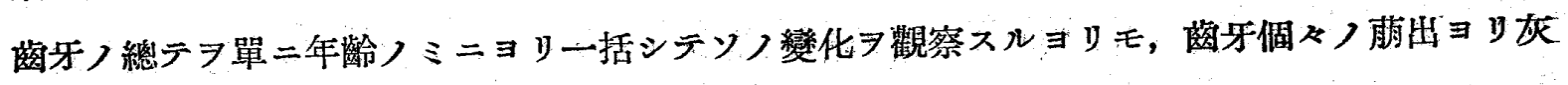
化完成へノ時期 得ルモノト云フラ得ベシ。而シテ刎論年龄的二八既二中年者二常二老人性變化つ最初ノモノト

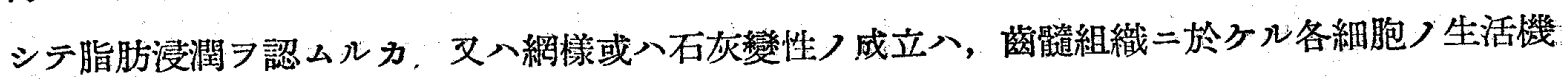

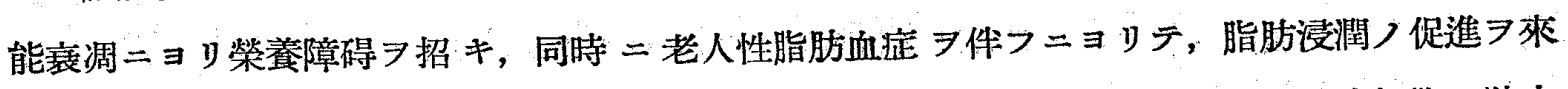

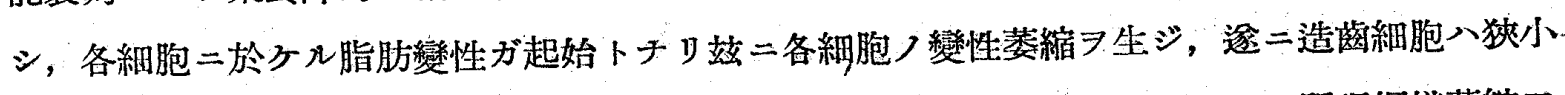

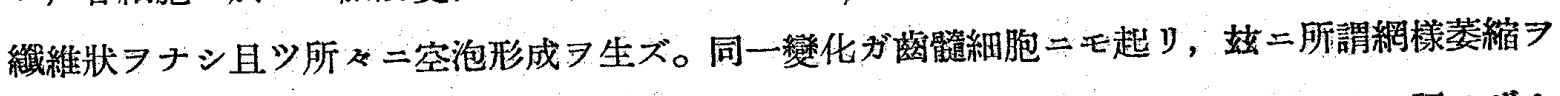
呈スル二至ルモノト信ズ。網樣萎縮二陷ルモ，必ズシモ常在性二脂肪 フソフ網眼內二認メザル コトアリ。斯カル現象八組織二於々ル脂肪沈着が決シテ不動性, 固着性二非ズ, 種ふナル要約 フ下二在曰テ變化 $\ni$ 生ジ得ルダメナリ。故二一旦脂肪沈着シ, 再ビ消失シ或八分解シ, 以テ他 フ成分二變化ズコトハ，他ノ病的現象例へバ動胍硬化，觕膜つ老人環等二於テ，ソノ陳舊性 ナルモノ二於テ八組織變性, 石灰沈著等ノ續笈變化ノミラ認メ, 脂肪习認メ得ザル事アル二徵

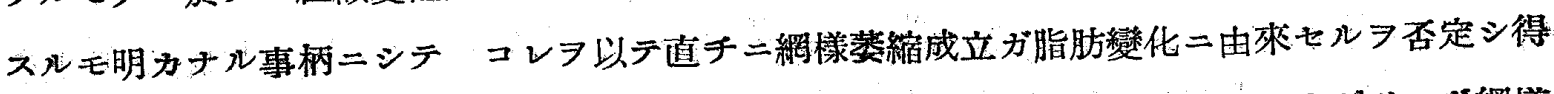
ルモノト八認メ得ズ。殊二若年者つ菌髓組織つ脂棜浸潤 變化フ見ルコトナキハ, 明カ二網樣變性ノ前驅症トシテ脂肪浸潤ノ出現スルフ證スルモフニシ

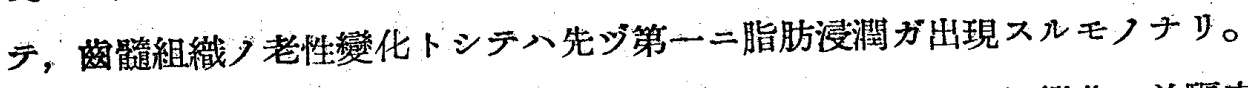

以上觀ジ來レバ健態永久苜牙組織つ脂肪浸潤入種ふナル老性變化ノ前駱症狀トシテ發現スル 


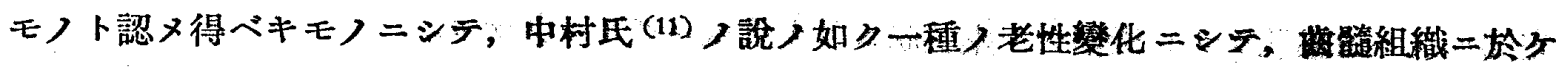

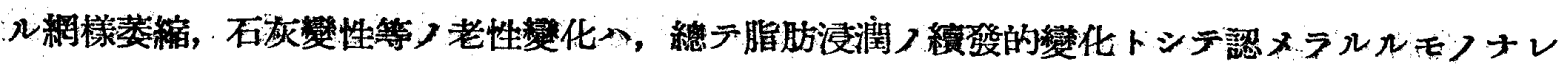

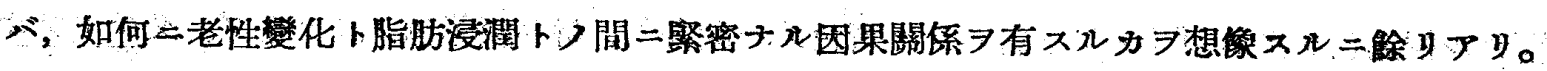

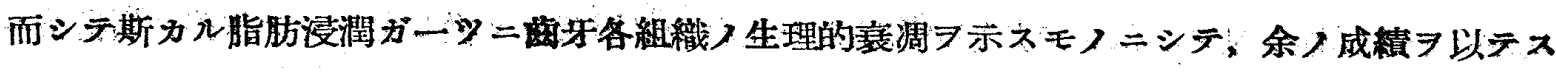

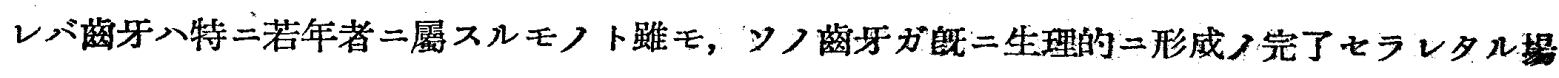

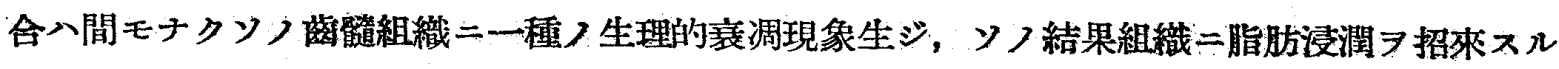

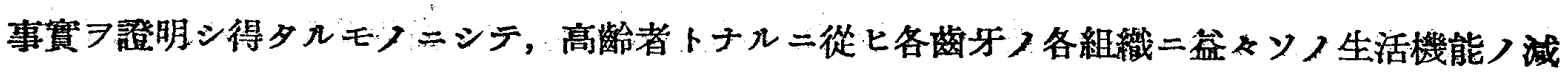

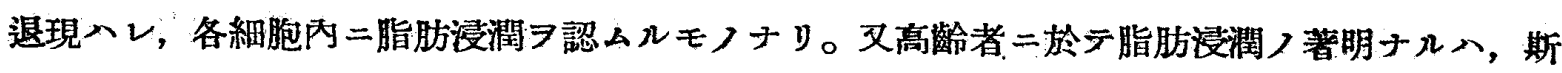
カル機能減退現象二加フル二, 一方老年者八脂肪血症八是卜相俟ツテ此處二組織入脂肪浸潤

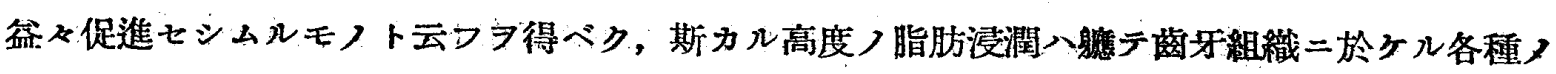
老性變化

\section{第 5 重 結 論}

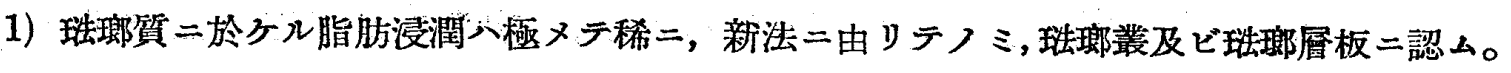

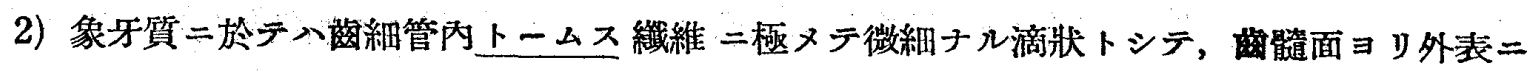

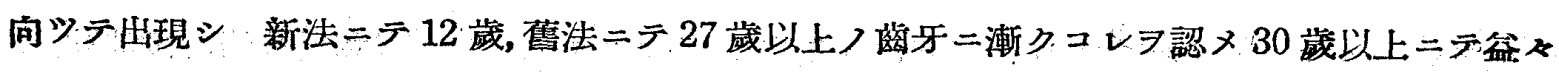
頻度〉增加习認么。

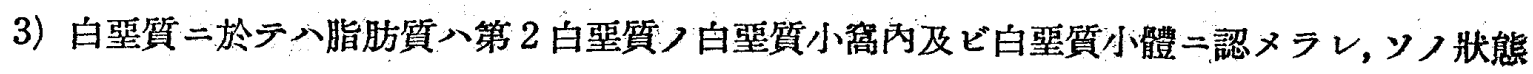

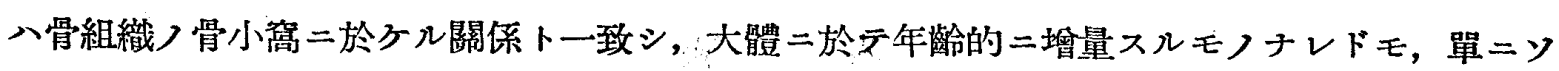
レノミナラズソノ脂肪ノ消長八齿根膜つ性狀及ビ周圍支持組織つ環境二影響七ラルル第 2 白垶 質內ノ白堅質小體自身つ退行性變化二十致スルモノノ如シ。從ツテュレガ脂肪所見

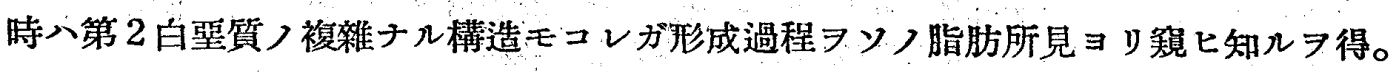

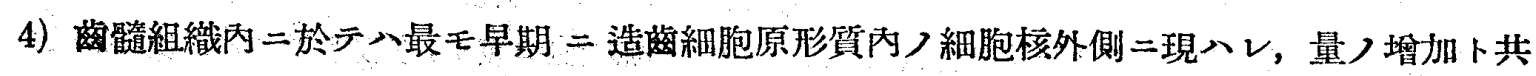

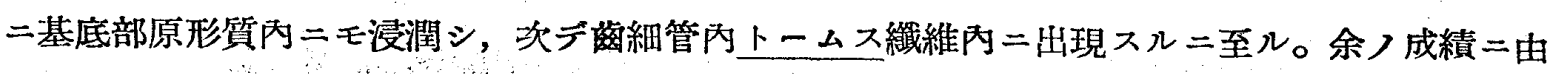
レバ新法ニテ 12 臓 舊法二於テ 14 歲つモつ二最モ早期二出現シ，夫レ以上八年齢ノ累加卜共 ニソノ出現頻度 一致入。

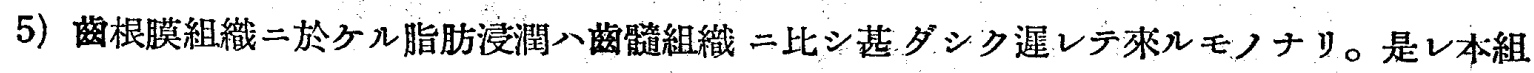
織ガ特二畐牙周園支持組織ト緊密ナル關係二アル二依ルベシ。然レトモ大體二於テ結締織細胞

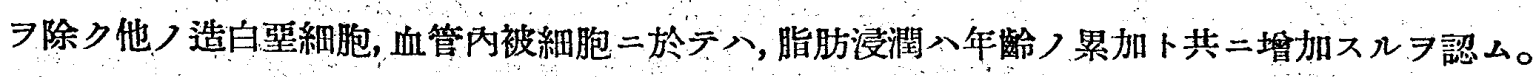

6）各組織二浸潤スル脂肪ノ形態八，舊法ニテ，主トシテ滴狀，稀二制月狀，指翰狀又八桿狀

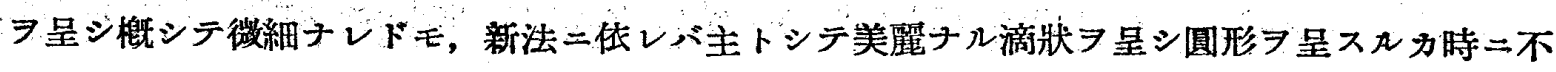


正圆形刃一斑點狀ヨナシ微細ナル塺埃狀ヨリ大滴狀二至ルモノナリ。

7）脂肪ノ色素二對スル反隹八，舊法ニテ光輝ナキ赤褐色又心黃赤褐色 麗ナル橙赤色 氏法二依り陽性 屬シ，又時ニハ小量ノ中性脂肪习モ認ムルコトアリ。

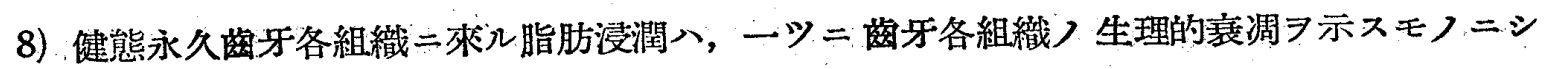
テ，若年者二認メラルル場合ト踓モコレフ詳細二觀察スルニ、ソノ蒛牙ガ既二形成ノ完了セル モノ二脂肪浸潤习來ス。コノ所見八明カニ一種ノ老性變化卜認メ得ベク，年路》累加ト共二脂

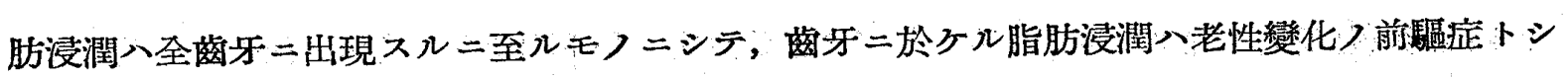

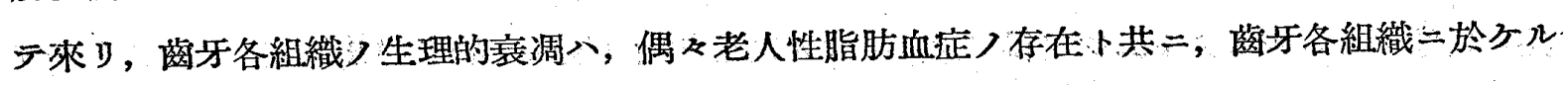

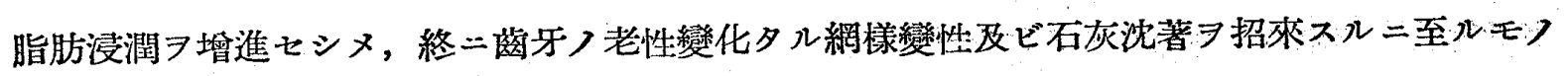
ヂルベシ

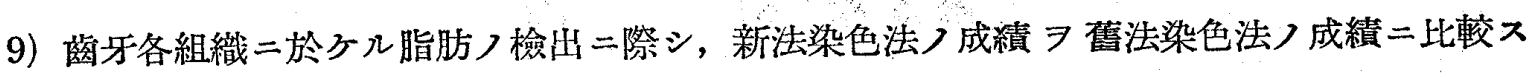
ル二, 新法染色法八常二顯著ナル成績 侉ホョク證明シ能ハザリシ脂肪質ノ存在フモ明暸ニシ得ル最モ優秀ナル脂肪染色法卜思考ス。

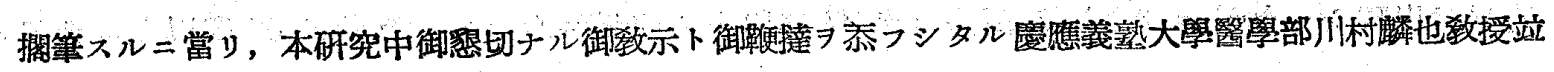

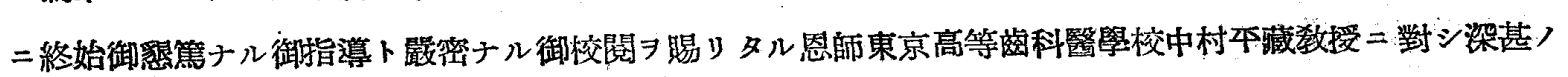
謝意ヨ表シ，劣亦終始御效莩

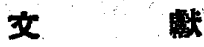

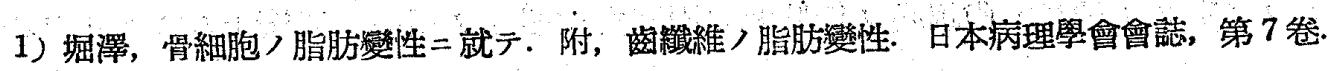

2) 服部, 間質性脂肪變性. 中央醫學雜誌. 第 28 卷. 第 $1,2,3,4$ 號.

3) 國分，齿牙脏瑯質二於ヶル脂肪出現二關スル知見補遺. 日本病理學會會誌，第 21 券，昭和 6 年.

4) 川村, 矢崎, 脂肪八一新染色法. 東京啙事新誌. 第 2823 號, 1933.

5) 川村, 矢崎, 再ビ余等, 脂肪染色法䍭二其, 基本液作製變法二就厂, 東京醫事新誌, 第 2867 號, 1934.

6) 川村 (麟)，人娟動物體内二於ヶル脂肪類，鑑別二就テ：日本病理學會會誌，第 1 卷.

7) 川村(麟)，人體及動物體二於ヶル脂肪問題二就テ形態學的竝二疑微化學的研究成樍. 日新醫學，第 7 年, 第 1 號.

8) 今, 硬固結締組織ノ脂肪變性殊二動脈硬化トコレトノ關係二就テ. 日本病理學會會誌, 第 4 卷:

9) 今, 脂肪質 以テ飼盖セラレタル動物ノ解剖學的研究知見: 日新醫學，第 4 年.

10) 川村(龮), 脾踻) 病理二就テ. 東京醫學會雜誌, 第 27 突.

11) 中村, 图牙脂肪; 形態學的研究. 北越䁷學會雜誌, 第 40 年, 第 1 號; 大正 14 年.

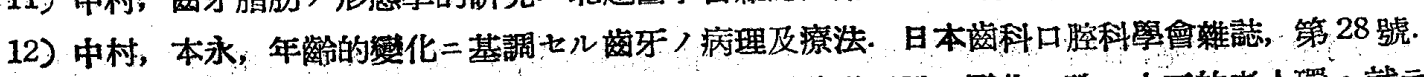

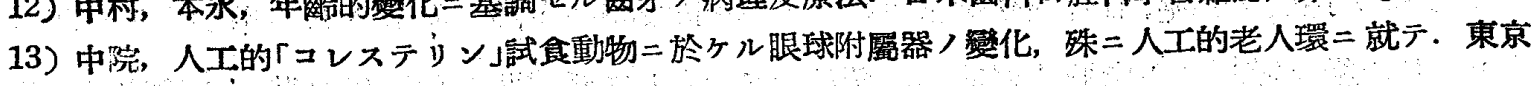
醫學會雜誌, 第 30 卷, 第 23 號, 大正 5 年.

14）中院，老性變化，形態學的研究：第 1 報告，第 2 報告，第 3 報告. 京都醫學會雜誌，第 15 卷. 第2 
號一第 16 第 8 號一第 18 卷，第 4 號.

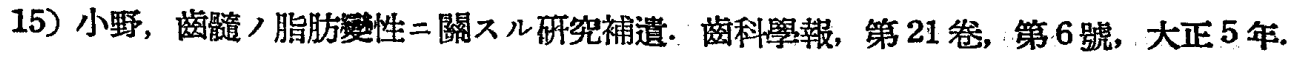

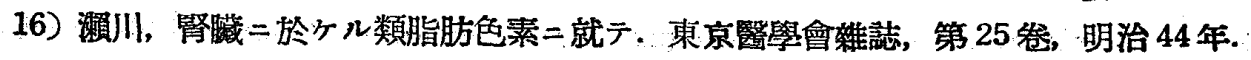

17）杤原，甲狀腺機能異常ガ阁牙及ビ其ノ支持組織 脂質=及ボス影響. 內分泌及實憸治療，第7卷， 第 1 號.

18）角田, 山田，人體乳於ヶル脂肪ノ川村矢崎氏新法ト普通法トニヨル染出狀熊ノ比較二就テ・米 科月報，第 14 绻，第 2 躆，1934.

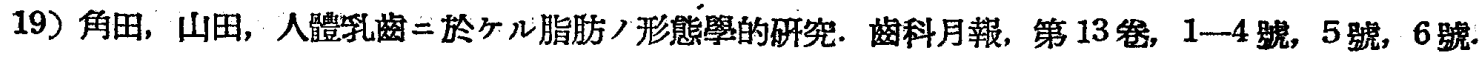

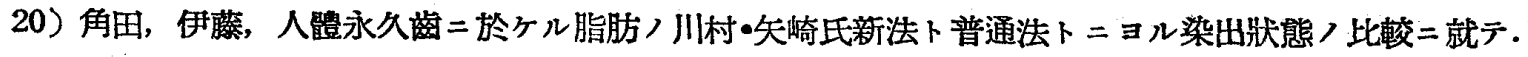
齿科月報，第 14 尞， 8 號.

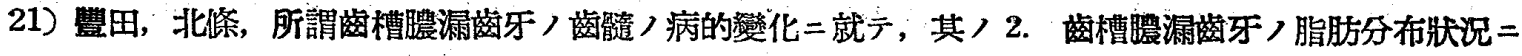
就テ. 日本之茼界, 昭和 11 年.

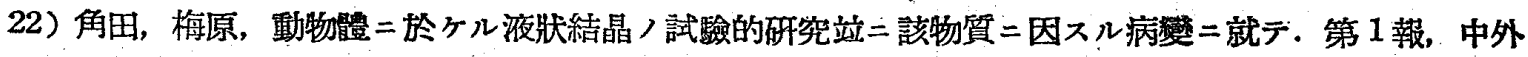
醫事新報, 864號.

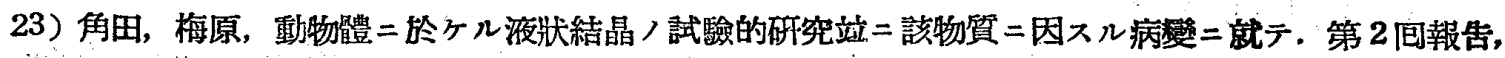
中外醫事新報, 865 號.

24）田中, 關節軟骨/老性燓化=就テ.日本病理學會會誌, 第 8 卷.

25）山極，山本，老人性腅關節端，變化二就テ．東京登學會猚誌，第 30 発，第 23 號，大正 5 年.

26) Aschoff, Zur Morphologie der lipoiden Subst. Ziegler's Beiträge, Bd. 47, 1910.

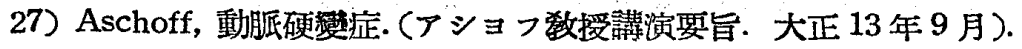

28) Anitschikow u. Chalatow, Über experimentelle Cholesterinsteatose und ihre Bedeutung für die Entstehung einiger Pathologischen Prozess. Zentralblatt f. Pathologie u. Pathologische Anatomie. Bd. 24, 1913.

29) Anitschikow, Über die Veraenderung der Kaninchenaorta bei experiment. Choresterinsteatose. Ziegler's Beiträge, Bd. 56, 1931.

30) Anitschikow, Über die Atherosklerose der beim Kaninchen u. deren Entstehung. Ziegler's Beitrage, Bd. 59, 1914.

31) Akamatsu, K., Das Vorkommen von Fett im Schmelz des Zahnes. V. f. Z., J. 45, S. 33, 1929.

32) Babes, Über das Auftreten von Fett im interstitiellen Gewebe der Niere und im Inneren der Nierengefässe, Zentralblatt f. allgem. Patholog. u. Patholog. Anatomie, 1908.

33) Fischer, Histologische Untersuchungen über den Fettgehalt der Nieren unter normalen und pathologischen Verhältnissen. Ziegler's Beiträge, Bd. 49, 1910.

34) M. Heider u. C. Wedl, Über Atrophien der Zahnpulpa. Deutsche Viertelj. f. Z., 5 Jahrg.

35) Jores, Wesen u. Entstehung der Arteriosklerose. Wiesbaden, 1903.

36) Jores, Über eine der fettige Metamorphose analoge Degeneration des elastischen Gewebes. Zentralblatt f. allg. Pathologie u. Path. Anatomie, Bd. 14, 1904.

37) Kokubun, S., Beiträge zur Lehre der Fettstoffwechselstörungen der Zahnpulpa unter Berücksichtigung der Pulpagefässe. V. f. Z. S. 189, 1931.

38) Marchand, Kongress der inneren Medizin, 1904.

39) Meyer, W., Die Vitalität des Zements. V. f. Z., Jg. 43, S. 488, 1927.

40) Preiswerk, Lehrbuch u. Atlas der Zahnheilkunde, 1908.

41) Prym, Markinterstitium der Niere. Virchow's Archiv, Bd. 196, 1909.

42) Poschiarisky, Zur Frage des Fettgehaltes der Milz. Ziegler's. Beiträge, Bd. 54, 1914. 
43) Ribbert, Uther die Genese ber arteriosklerotischen Veränderungen der Intima. Verhand. d. Deutschen Patholog. Gesellschaft, 8. Tag. 1904.

44) J. Szabo, Die Grössverhăltnisse des Cavum Pulpae nach Altersystem. Oestreichischungarische Viertelj. f. Z., X, VI, 1900.

45) Starokadomshy u. Sabelow, Zur Frage experiment. Atherosklerose. Frankf. Zeitschr. f. Pathologie, Bd. 3, 1909.

46) Shmamine, T., Das sekundäre Zement. Deutsche. Zheilk., 13, 1910.

47) K. Trueb, Grösseverhältnisse des Cavum Pulpae nach Alterstufen. Deutsche Monatsschr. f. Z., Jahrg. 27, 1909.

48) Virchow, Der atheromatöse Prozess der Arterien. Wiener. Med. Wochenschrift, 1856.

49) Verse, M., Über die Augenveränderungen (Lipoidosis oculi) bei der experiment. Lipoidocholesterinämie des Kaninchens. Virchow's Archiv, Bb. 250, 1924.

50) C. Wedl, Pathologie der Zähne, II. Bb., 1903.

51) Wacker u. Hueck, Utber experiment. Atherosklerose u. Cholesterinaemie. Deutsche Med. Woch., 1912, Nr. 38.

52) Wacker u. Hueck, Chemie. u. Patholog. Untersuchungen über die Bedeutung der Cholesterinism. Archiv. f. experiment. Pathologie u. Pharmakologie, Bb. 74, 1913.

53) Weber, R., Über die Verfettung der Odontoblastenfortsätze. Z. Rund. schau, S, 316, 1925.

54) Weber, R., Zur Kenntnis des Auftretens von Fett am Zahn. V. f. Z., Jg. 42, S. 64, 1926.

55) Willner, Hans, Utber fettige Degeneration der Pulpa. D. Z. W., Nr. 3,1926.

\section{附 圖 說 明}

第 1 圖 28 歲|1，锆組織及ビ象牙質二於ヶル脂肪所見。
A : 70\%「アルニール」でダソ」染染
B: 40\%「アルコール」「ズダン」染色

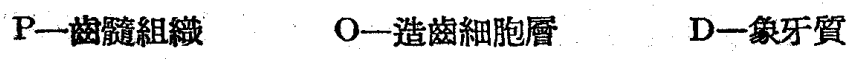

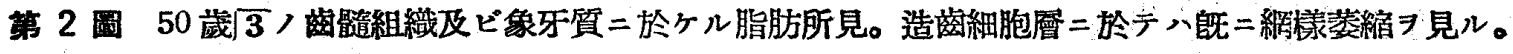

A: 70\%「アルコール」「ズダン」染色

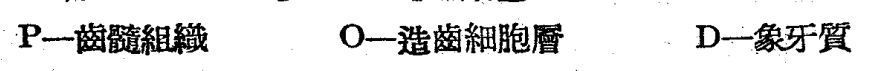

3 圆 27 歲 $\sqrt{8}$ ，第 2 白型質，白型質小體二於ヶル脂肪所見。
A : 70\%「アルュール」「ズダン」染色
B : 40\%「アルュール」「ズダン」染染色
D一象牙質 $\quad Z_{I}$ 一原成白瑟質 


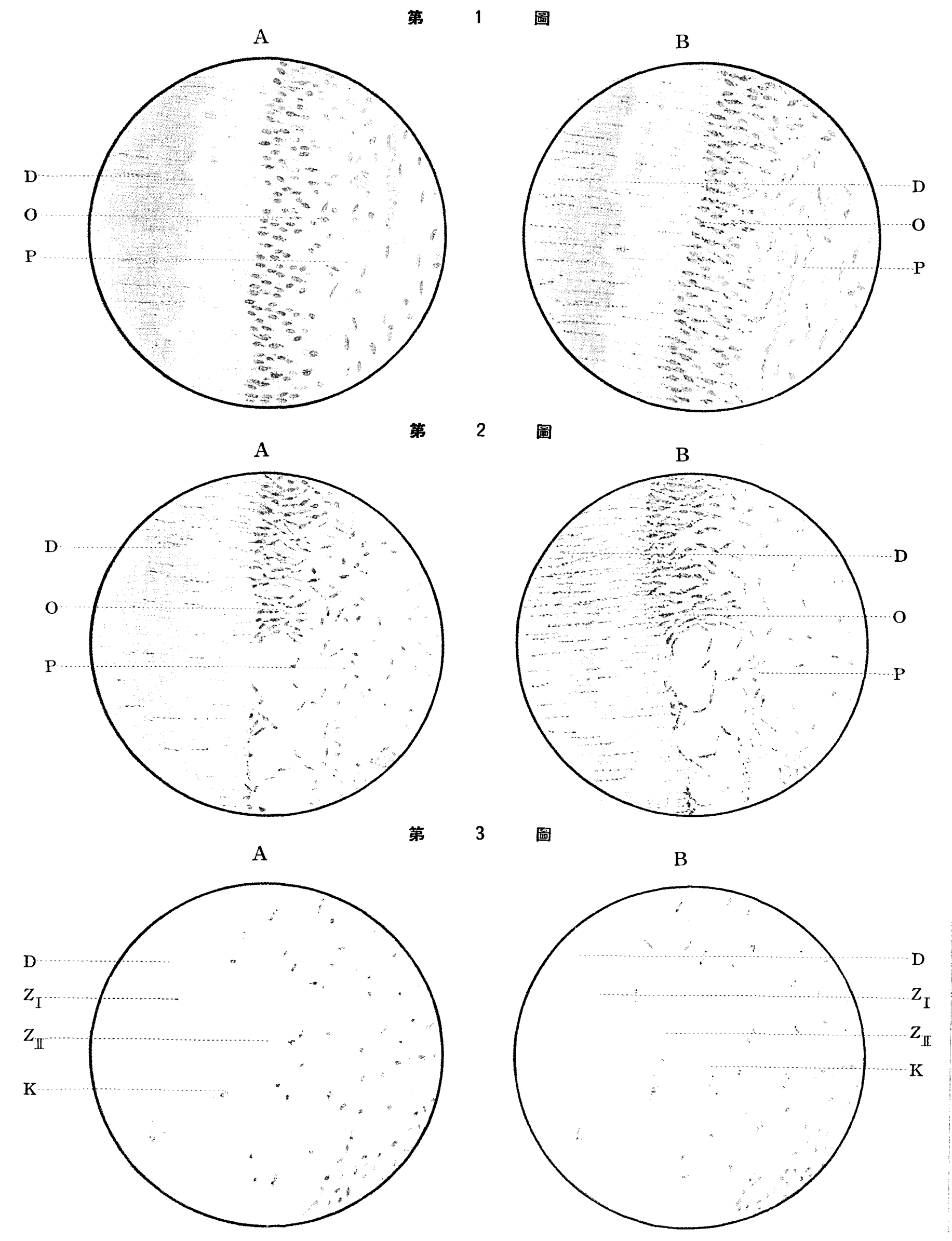

